\title{
Synthesis and binding affinity studies of muscarinic receptor antagonists related to dehydrohimbacine
}

\author{
Ling-Jie Gao, ${ }^{a}$ Gunther Van Cauwenberge, ${ }^{a}$ Noël Hosten, ${ }^{a}$ Dirk Van Haver, ${ }^{a}$ \\ Magali Waelbroeck, ${ }^{b}$ Pierre J. De Clercq* ${ }^{a}$ \\ ${ }^{a}$ Department of Organic Chemistry, Ghent University, Krijgslaan 281, B-9000 Gent, Belgium, \\ and ${ }^{b}$ Laboratoire de Chimie Biologique et de la Nutrition, Université Libre de Bruxelles, \\ Route de Lennik 808, B-1070 Brussels, Belgium \\ E-mail : pierre.declercq@rug.ac.be
}

Dedicated to Professor Georges Hoornaert on his $65^{\text {th }}$ birthday

(received 02 Oct 02; accepted 20 Dec 03; published on the web 03 Feb 03)

\begin{abstract}
The intramolecular Diels-Alder reaction of bromo-substituted nonatrienoate 24 leads to a mixture of the anti-adducts $\mathbf{2 5 a}$ and $\mathbf{2 5 b}$, in which the trans-fused lactone $\mathbf{2 5} \mathbf{b}$, the result of an expected exo-addition, predominates (6.2:1 stereoselectivity). Further introduction of a 2,6-transdisubstituted piperidine ring (26 and 27) via palladium catalyzed cross-coupling reactions (Stille and Sonogashira) affords intermediates that are easily transformed into dehydrohimbacine derivatives 14a, 14b, 15a, and 15b. Binding affinity studies for the muscarine receptors $M_{1}, M_{2}$, $M_{3}$, and $M_{4}$ show that 15a possesses a 18-fold selectivity for the $M_{2}$ relative to the $M_{1}$ receptor, but with concomittant loss in affinity compared to the naturally occurring $(+)$-himbacine (1), a recognized muscarinic receptor antagonist.
\end{abstract}

Keywords: Himbacine, muscarinic receptor, synthesis

\section{Introduction}

Since memorable times natural products with characteristic biological activities have constituted attractive targets for total synthesis, especially when their structures offer some challenging features with regard to connectivity, functionality and/or stereochemistry. In this context recently there has been interest in the synthesis of a series of piperidine alkaloids 1-5 (Figure 1), several of which have been isolated from the bark of Galbulimima baccata, a species belonging to the magnolia family found in New Guinea and North Queensland. ${ }^{1}$ The structure of $(+)$-himbacine $(\mathbf{1}){ }^{2}$ the most representative member of the family, was determined in 1962 via an X-ray diffraction study of the corresponding hydrobromic salt. ${ }^{3}$ 


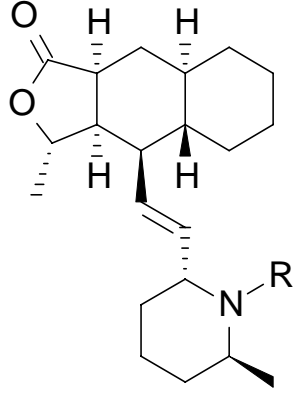

$1 \mathrm{R}=\mathrm{Me}$ himbacine

$2 \mathrm{R}=\mathrm{H}$ himbeline

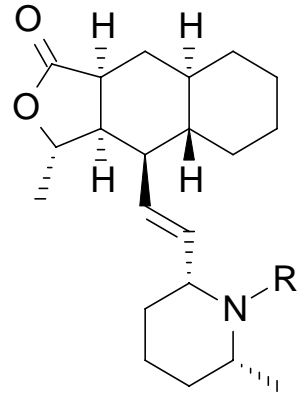

$3 \mathrm{R}=\mathrm{Me}$

$4 \mathrm{R}=\mathrm{H}$ himandravine

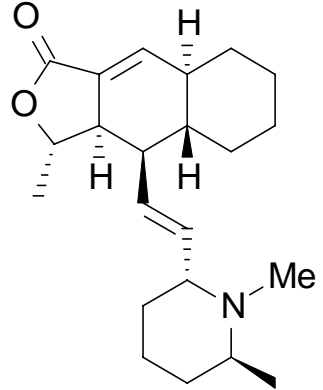

5 himgravine

\section{Figure 1}

Medicinal interest in himbacine originates from the finding that it is a potent muscarinic receptor antagonist that displays selectivity for the $\mathrm{M}_{2}$ receptor. ${ }^{4}$ Already in 1914 Dale proposed that acetylcholine (ACh) acts through two major receptor subtypes defined as nicotinic and muscarinic. ${ }^{5}$ These receptors differ in location, function, structure and receptor-effector coupling mechanisms. Whereas nicotinic receptors are ligand-gated cation channels, muscarinic receptors are members of a superfamily, also including e.g. the opsins, which transmit their signal through GTP-binding proteins. This receptor family is structurally characterized by seven hydrophobic regions which span the membrane. ${ }^{6}$

In the late $1900 \mathrm{~s}$, five different subtypes $\mathrm{m}_{1}$ to $\mathrm{m}_{5}$ of the muscarinic receptor were identified using molecular biology techniques. ${ }^{7}$ Their expression in cultured cells devoid of any endogenous muscarinic receptors led to the pharmacological and biological characterization of the five subtypes $\mathrm{M}_{1}-\mathrm{M}_{5} .{ }^{8}$ The pharmacological properties of the cloned receptors are, as a rule, in excellent agreement with the binding as well as with the functional properties of the naturally expressed receptors $\mathrm{M}_{1}-\mathrm{M}_{4}$. These are distributed throughout the body where they regulate vital functions in both the central and autonomic nervous system. The $\mathrm{M}_{2}$ and $\mathrm{M}_{3}$ receptors are widely expressed in peripheral tissues, where the effector organs include heart $\left(\mathrm{M}_{2}\right)$, smooth muscle and exocrine glands $\left(\mathrm{M}_{3}\right)$. All five muscarinic receptor mRNAs have been identified in the central nervous system by in situ hybridization. ${ }^{9}$

The muscarinic receptor subtypes $\mathrm{M}_{1}-\mathrm{M}_{5}$ can further be divided into two categories, both on the basis of their sequence homology and of their signaling mechanism. The $\mathrm{M}_{1}, \mathrm{M}_{3}, \mathrm{M}_{5}$ form a first homologous group that is known to activate phospholipase $\mathrm{C}$, which results in increased intracellular $\mathrm{Ca}^{2+}$ concentrations, and cellular excitation. The $\mathrm{M}_{2}, \mathrm{M}_{4}$ receptors form a second homologous group that inhibits adenylate cyclase, closes $\mathrm{Ca}^{2+}$ and open $\mathrm{K}^{+}$channels, resulting in the hyperpolarization of the membrane and inhibitory signaling.

The age-related neurodegenerative diseases, such as Alzheimer's disease, have been associated with loss of cholinergic innervation and reduced levels of synaptic acetylcholine in several brain areas. ${ }^{10}$ The cholinergic approach to the treatment of the disease is directed towards 
the enhancement of ACh levels. Whereas this goal can in principle be achieved by inhibitors of cholinesterase, ${ }^{11}$ the use of postsynaptic $\mathrm{M}_{1}$ agonists has also been proposed, ${ }^{12}$ especially since the $M_{1}$ subtype is almost absent in peripheral effector organs and the number of postsynaptic receptors seems not to be altered. An alternative strategy focuses on the blocking of the presynaptic $\mathrm{M}_{2}$ receptor subtypes, activation of which inhibits the release of ACh. ${ }^{13}$ Obviously, in the latter case $\mathrm{M}_{2}$ antagonists with $\mathrm{M}_{1} / \mathrm{M}_{2}$ selectivity are required.

Several antagonists have been useful in the classification of muscarinic receptor subtypes. ${ }^{14}$ Next to pirenzepine whose selective $\mathrm{M}_{1}$ antagonistic activity was discovered in the early $1980 \mathrm{~s},{ }^{15}$ others have included 4-diphenylacetoxy- $N$-methylpiperidine methiodide (4-DAMP), hexahydrosiladifenidol (HHSiD), gallamine, the benzodiazepinone derivative AF-DX 116 and himbacine. ${ }^{16}$ Interestingly, it has also been demonstrated that the blocking action of gallamine and himbacine on the heart differed from competitive inhibition, but could be rationalized by an allosteric mechanism. ${ }^{17}$

In general the known muscarinic agonists and antagonists are not very selective. ${ }^{18}$ Himbacine however has been reported to bind to $\mathrm{M}_{2}$ receptors with $\mathrm{K}_{\mathrm{d}}$ values of 4.6-10 $\mathrm{nM}$ and with a 10-20 fold selectivity against the $M_{1}$ receptor. The full selectivity pattern $M_{1}-M_{4}$ of himbacine in binding studies with rat brain receptor subtypes has been reported. ${ }^{19}$
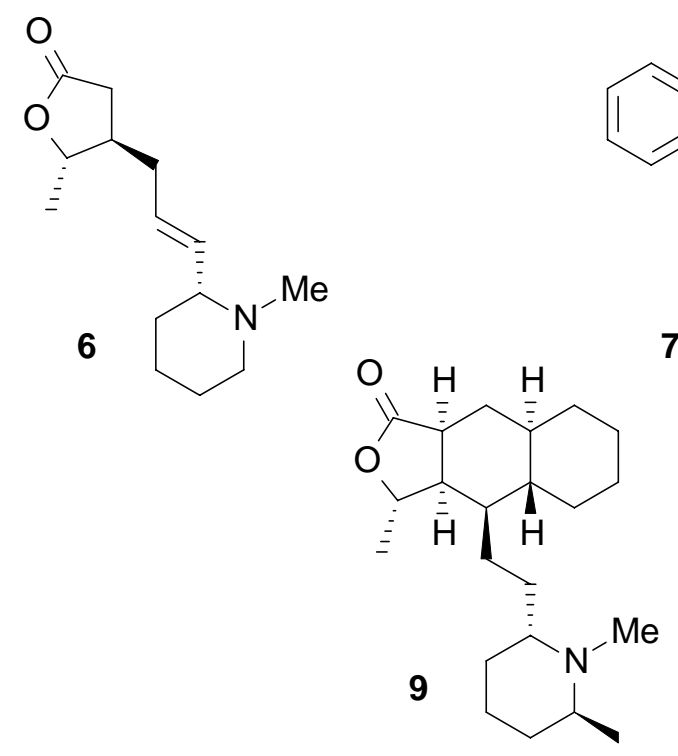

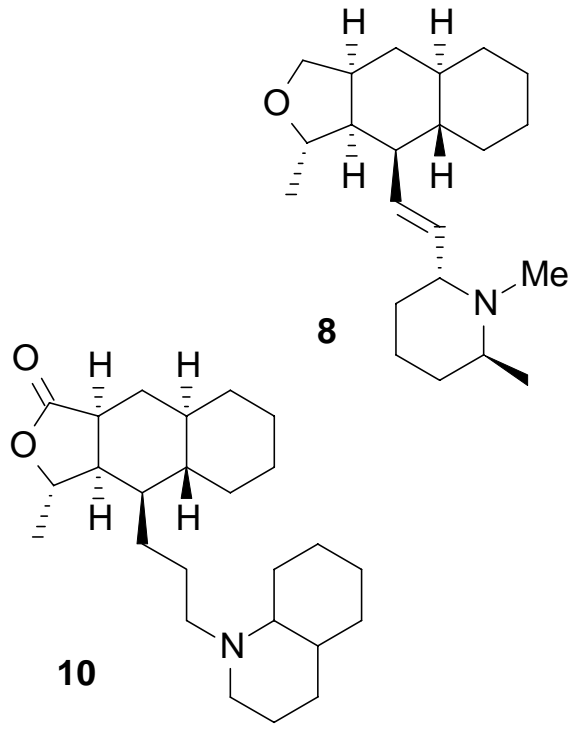

\section{Figure 2}

In an early structure-activity relationship study the natural alkaloids $(\mathbf{1}, \mathbf{2}, \mathbf{4}, \mathbf{5})$ and their corresponding dihydro-derivatives were evaluated as antagonists of muscarinic receptors in guinea-pig ileal longitudinal muscle and electrically stimulated left atrium. ${ }^{20}$ Himbacine was the most potent compound and displayed a 15-fold selectivity for the $\mathrm{M}_{2}$ receptor. Reduction of the double bond in himbacine or removal of the $N$-methyl group (cf. himbeline, 2) led to reduced selectivity. The same trend was observed in subsequent structure-activity relationship studies 
aiming at the development of himbacine analogues with high potency (better than $1 \mathrm{nM}$ ) and selectivity (better than 100-fold). ${ }^{21}$ Structures 6-8 (Figure 2) are representative molecules and their binding affinities at $\mathrm{M}_{2}$ sites and $\mathrm{M}_{1} / \mathrm{M}_{2}$ selectivities are given in Table 1. Compared to himbacine the severely truncated analogue 6 lost both affinity for the $M_{2}$ receptor (about 260fold) and selectivity. ${ }^{21 a}$

Table 1. $\mathrm{K}_{\mathrm{i}}$ values $(\mathrm{nM})$ reported for himbacine (1) and compounds 6-13

\begin{tabular}{ccc}
\hline Compound & $\mathrm{M}_{2}$ & $\mathrm{M}_{1} / \mathrm{M}_{2}$ \\
\hline $\mathbf{1}^{\mathrm{a}}$ & 11 & 6.5 \\
$\mathbf{6}^{\mathrm{b}}$ & 1210 & 8 \\
$\mathbf{7}^{\mathrm{c}}$ & 3.2 & 0.5 \\
$\mathbf{8}^{\mathrm{d}}$ & 353 & 0.5 \\
$\mathbf{9}^{\mathrm{e}}$ & 4.3 & 7.5 \\
$\mathbf{1 0}^{\mathrm{e}}$ & 13 & 2.9 \\
$\mathbf{1 1}^{\mathrm{f}}$ & 1.0 & 140 \\
$\mathbf{1 2}^{\mathrm{g}}$ & 310 & 10.4 \\
$\mathbf{1 3}^{\mathrm{g}}$ & 170 & 10.2 \\
\hline
\end{tabular}

${ }^{\text {a }}$ Competition experiments with $\left[{ }^{3} \mathrm{H}\right]-N$-methyl scopolamine at $25{ }^{\circ} \mathrm{C}$ in a $50 \mathrm{mM}$ sodium phosphate/ $2 \mathrm{mM} \mathrm{MgCl}$ buffer ( $\mathrm{pH}$ 7.4) at rat muscarinic receptors: $\mathrm{M}_{1}$ in brain, $\mathrm{M}_{2}$ in heart. ${ }^{\mathrm{b}}$ Reference 21a. ${ }^{\mathrm{c}}$ Reference 21b. ${ }^{\mathrm{d}}$ Reference 21c. ${ }^{\mathrm{e}}$ Reference 22. ${ }^{\mathrm{f}}$ Reference 23. ${ }^{\mathrm{g}}$ Reference 24.

Whereas the replacement of the original tricyclic moiety of himbacine with a dihydroanthracene core as in 7 leads to an increase in affinity at the $M_{2}$ receptor subtype, a preferential binding at the $\mathrm{M}_{1}$ receptor subtype is now observed. ${ }^{21 \mathrm{~b}}$ The importance of the structural integrity of the $\mathrm{ABC}$-ring part, including the heterocyclic ring, for optimal $\mathrm{M}_{2}$ selectivity was also confirmed by the observation that the removal of the carbonyl oxygen of himbacine affords a molecule (8) with reduced affinity and inversed selectivity. ${ }^{21 \mathrm{c}}$ Finally, an interesting series of analogues has been developed by Chackalamannil on the basis of their finding that dihydrohimbacine (9) has a potency and selectivity comparable to that of himbacine in cloned human $\mathrm{M}_{1}$ and $\mathrm{M}_{2}$ receptors. ${ }^{22}$ Various $N$-alkylated derivatives such as $\mathbf{1 0}$, in which the nitrogen atom is located at the same relative position to the intact $\mathrm{ABC}$-ring as in himbacine, were prepared. Several of these analogues display a potency comparable to that of himbacine, but again at the expense of selectivity. In essence, so far, analogue development on the basis of the himbacine skeleton has not met the expectations. In contrast, in another structural series, highly active compounds such as $\mathbf{1 1}$ (Figure 3 ) with $>100$-fold selectivity against $\mathrm{M}_{1}, \mathrm{M}_{3}$, and $\mathrm{M}_{5}$ receptors have been developed. ${ }^{23}$ 


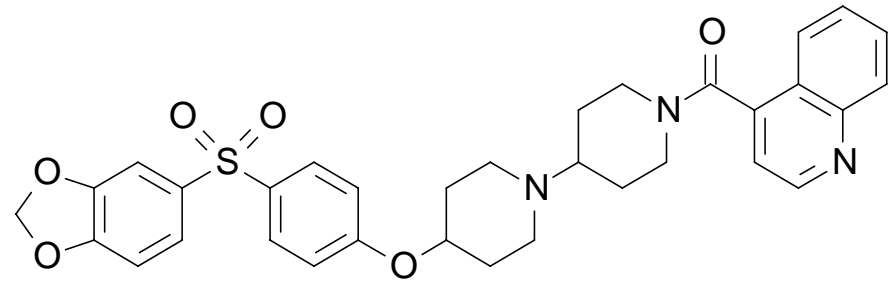

11

Figure 3

\section{Results and Discussion}

Inspired by the above SAR studies that indicate that the deletion of substantial parts of the skeleton and/or functionality of the natural derivative results in loss of selectivity, we recently became interested in the synthesis of intact stereoisomers of himbacine with focus on the stereogenic centers in the tricyclic system of the molecule. ${ }^{24}$ Also variations in the geometry of the two carbon interconnecting unit between the two cyclic parts of the molecule were investigated, i.e. the incorporation of an acetylenic and of a (Z)-ethylenic next to the natural $(E)$ ethylenic bridge. Three different isomeric series were synthesized, which, in combination with the three different above mentioned interconnecting units, afforded nine derivatives, including synthetic (+)-himbacine. Interestingly, the binding affinity studies showed that, next to himbacine, the two analogues 12 and 13 (Figure 4) possess a moderate 10-fold selectivity for the $\mathrm{M}_{2}$ receptor, albeit with reduced potency (Table 1). Analogue 12 is epimeric at C-4 and at C-4a relative to himbacine whereas analogue 13 corresponds to 11,12-dehydrohimbacine. In a further search at optimizing both the potency and $\mathrm{M}_{2} / \mathrm{M}_{1}$ selectivity of himbacine-like derivatives we wish to report now on the synthesis of a few stereoisomeric derivatives $\mathbf{1 4}$ and $\mathbf{1 5}$ characterized by the presence of (i) a double bond at C-4,C-4a and of (ii) an interconnecting two carbon unit of the $(E)$-ene or yne type, and in which the other structural features of himbacine are kept intact. At the conceptual level, derivatives within the a-configurational series, such as 14a and 15a, were preferred. They respect the structural integrity of the two cyclic parts of himbacine and include a bridging unit, which by its nature imposes an extended geometry to the molecule, presumably a crucial factor in determining the biological activity.

For a synthetic chemist, himbacine (1) possesses an attractive structure. Its skeleton consists of a tricyclic $\mathrm{ABC}$-ring system, to which is connected, via a (E)-double bond, the $N$-methyl piperidine D-ring. The $\mathrm{ABC}$-ring part itself consists of a trans-fused perhydronaphtalene with a cis-fused $\gamma$-lactone. The two cyclic parts also display interesting stereochemical patterns: in the ABC-ring part six contiguous stereocenters are present, while the D-ring features a less common 2,6-trans-disubstituted piperidine ring. The first enantioselective total synthesis of himbacine was reported by Hart and Kozikowski in $1995 .{ }^{25}$ Other enantioselective syntheses of himbacine have been subsequently reported by Chackalamannil, ${ }^{26}$ by Terashima, ${ }^{27}$ and by De Clercq. ${ }^{28}$ 

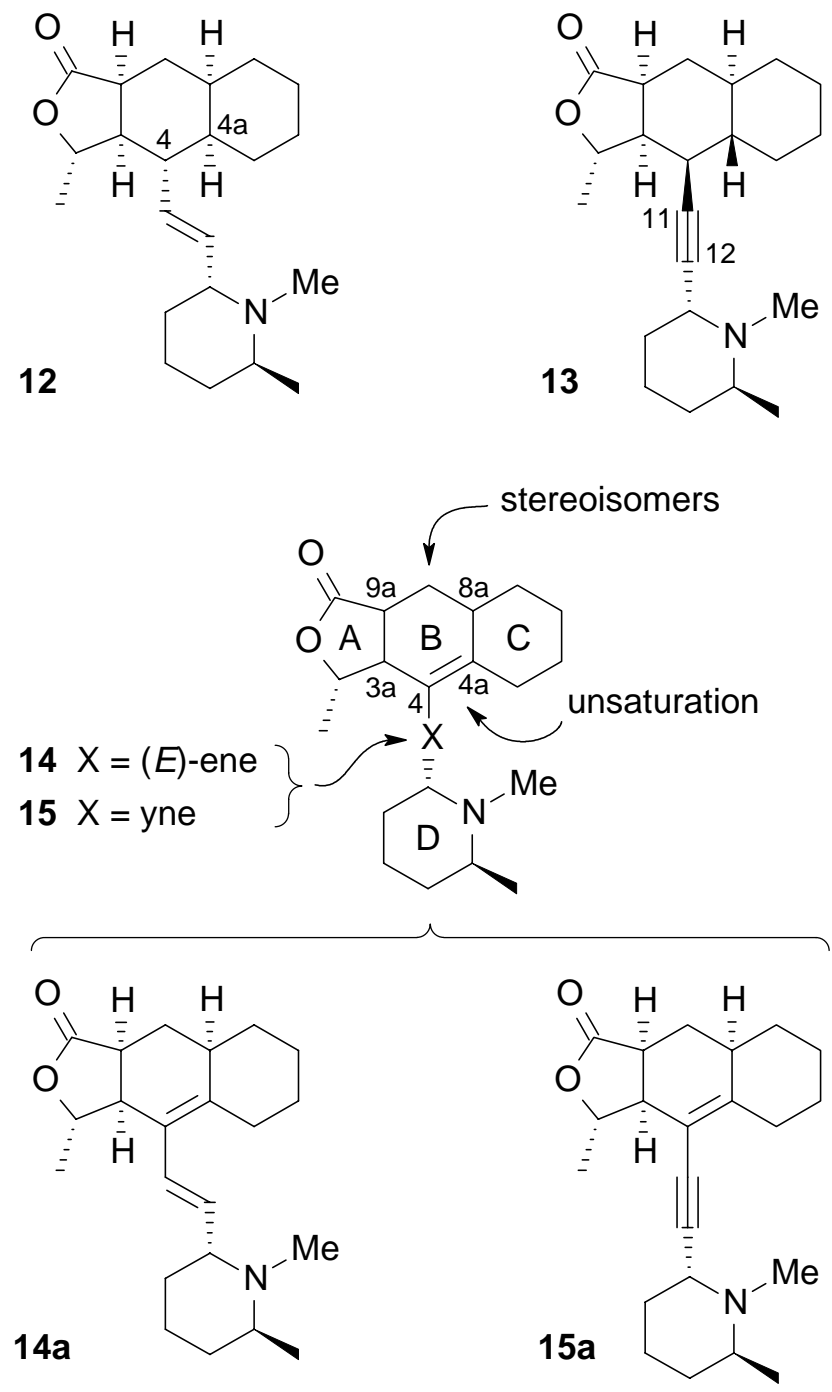

\section{Figure 4}

So far the various total synthetic approaches towards himbacine have all involved the use of a Diels-Alder reaction in establishing the central B-ring nucleus of the ABC-ring skeleton. ${ }^{25,26,27,28}$ Among the six different bond construction sets that one may distinguish following this particular cycloaddition strategy, two sets correspond to the intermolecular reaction mode, one of which has been realized in practice, ${ }^{27}$ and the four remaining construction sets correspond to intramolecular versions of this popular construction reaction (IMDA). ${ }^{29}$ Symptomatic of how pervasive this reaction type has become in terms of cyclic skeleton construction, especially when involving stereochemical constraints, is the observation that the three synthetic approaches that were first reported almost simultaneously in 1995, involved pathway $\mathrm{i}$ (Scheme 1). ${ }^{25,30,31}$ One of the benefits of this particular cycloaddition route resides in the obtainment of the functionalized ABC-ring system as present in himgravine (5), whose selective reduction to himbacine (1) has been reported before. ${ }^{2}$ Also, depending on the reaction 
conditions and the nature of the $\mathrm{R}$ group, the stereochemical outcome of the process could be directed towards the himbacine-like configuration. ${ }^{25 \mathrm{~b}}$ A second construction set (ii) was exploited successfully by Chackalamannil in the total syntheses of himbacine and more recently of himandravine. ${ }^{26,32}$ This cycloaddition whereby the R group already contains the intact D-ring leads exclusively to one stereoisomer in which the $\gamma$-lactone is trans-fused, the result of an anti,exo-approach (vide infra).
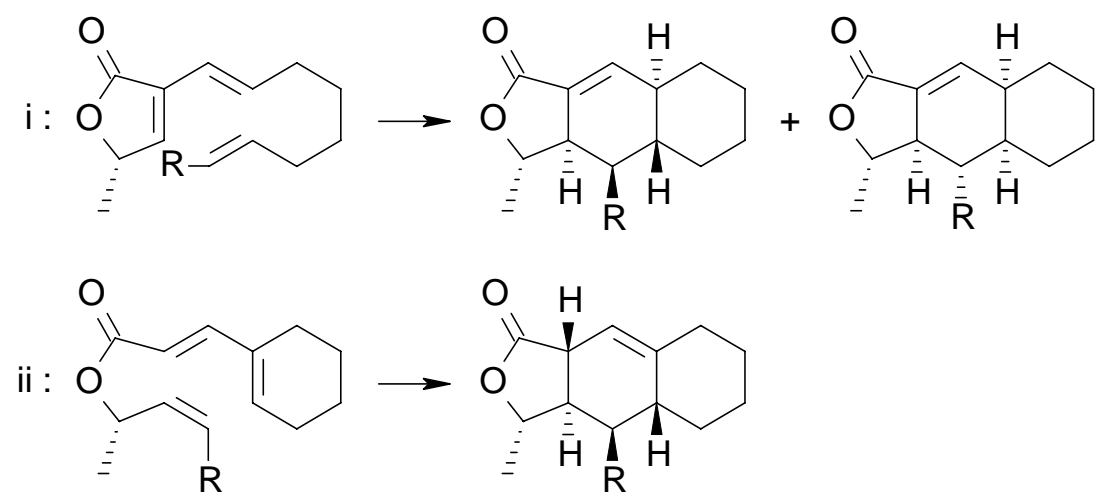

\section{Scheme 1}

In the present study we wish to elaborate on the construction set shown in Scheme $2 .{ }^{33}$ This third pathway bears some analogy with the previous approach since in both cases the intramolecular cycloaddition leads to the simultaneous formation of the A- and B-rings. This novel strategy involves as a key step the cycloaddition of an acrylate derived from a 3,4,5trisubstituted pentadienyl alcohol bearing a stereocenter (i.e., at C-1) in the diene/dienophile tether that is expected to play a stereodirecting role in the process. Following our preliminary report on this work, ${ }^{33 a}$ an almost identical synthetic approach has been disclosed by Sherburn and co-workers. ${ }^{33 \mathrm{~b}}$ The stereochemical outcome of the Diels-Alder reaction is determined by (1) the anti- or syn-approach of the dienophile relative to the orientation of the methyl group at $\mathrm{C}-1$ on the planar pentadienyl moiety, and by (2) the exo- or endo-mode of addition. On one hand the anti-approach should be preferred on the basis of steric considerations, especially when $\mathrm{R}$ is voluminous, thus favoring the $\mathbf{a}$ - and $\mathbf{b}$-configurations; on the other hand the exo-mode of addition is expected here on the basis of a literature precedent dealing with the synthesis of drimane sesquiterpenes. ${ }^{34}$ Hence at the outset the preferred anti,exo-formation of the b-type stereoisomeric relationship was anticipated. As will be discussed later in more detail a very recent joint synthetic computational investigation into the optimization of the stereoselectivity in the IMDA reaction of pentadienyl acrylates has corroborated this expectation. ${ }^{35}$ Subsequent isomerization of the trans-fused lactone (b) to the more stable cis-configuration should afford the desired stereochemistry (a) as present in derivatives 14a and 15a. A further strategic choice allowing for the convergent synthesis of both 14 and 15, which only differ in the connecting unit, consists of the incorporation of a vinylic halogen atom (i.e., $\mathrm{R}=\mathrm{Br}$ ), whose replacement using 
one of the several existing cross-coupling reactions, should allow for the completion of the carbon framework of the molecule possessing the genuine D-ring as in $\mathbf{1 4}$ and $\mathbf{1 5 .}$

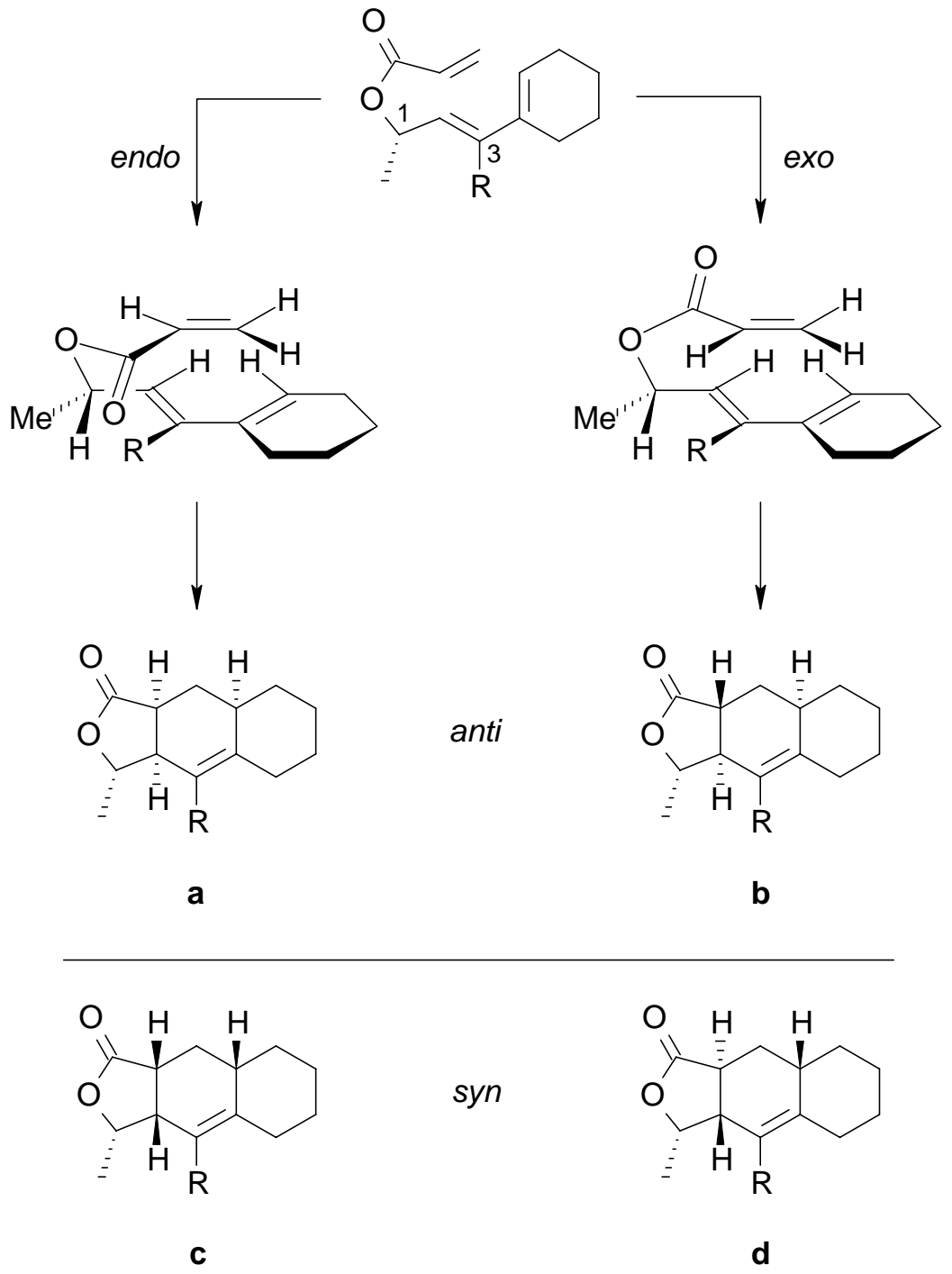

Scheme 2

Central in the approach following the above strategy stands alcohol 23, whose synthesis is outlined in Scheme 3. After protection of the hydroxyl group in (S)-ethyl lactate as tertbutyldimethysilyl ether, the resulting ester $\mathbf{1 6}$ was reduced with diisobutylaluminum hydride affording aldehyde 17 (80\% yield). ${ }^{36}$ Conversion of the latter using the protocol of Corey-Fuchs $^{37}$ gave the known geminal dibromo substituted alkene 18 (84\% yield). ${ }^{38}$ The stereoselective introduction of the cyclohexenyl moiety was then realized via a Stille coupling with stannane $20 .{ }^{39}$ The latter was obtained in 79\% yield by reaction of enol triflate 19 with hexamethylditin (tetrakis(triphenylphosphine)palladium(0), lithium chloride, THF, $60{ }^{\circ} \mathrm{C}$ ). ${ }^{40}$ Several studies have recently appeared involving the replacement of one or both halogen atoms in 1,1-dibromo-1-alkenes. ${ }^{41}$ In particular the stereoselective replacement of the (E)-halogen atom 
using the Stille reaction has been studied in detail by Shen and Wang. ${ }^{41 a}$ Using the same optimized reaction conditions, tris(dibenzylideneacetone)dipalladium(0) and tri-2-furylphosphine in refluxing toluene, vinyl bromide 21 was obtained in $71 \%$ yield. Although the $(Z)$ stereochemistry at the trisubstituted double bond was expected, its unambiguous configurational assignment followed from the stereospecific transformation of $\mathbf{2 1}$ into C-silylated alcohol 22 after treatment with tert-butyllithium at $-78{ }^{\circ} \mathrm{C}$. This rearrangement that follows a metal-halogen exchange implies, of course, a cis-relationship between the halogen atom and the silyloxyethyl group. Desilylation of 21 with tetrabutylammonium fluoride afforded alcohol 23 in $88 \%$ yield.
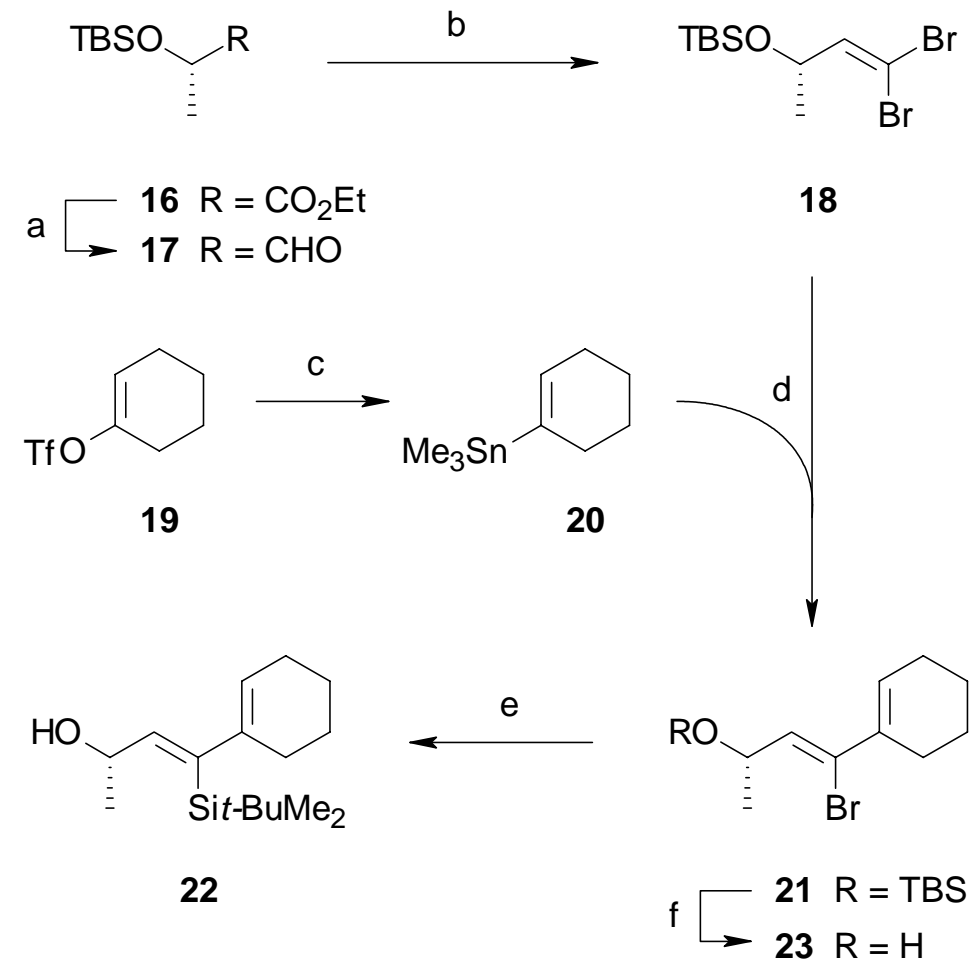

Scheme 3. (a) DIBAL-H, toluene, $-78{ }^{\circ} \mathrm{C}, 2 \mathrm{~h}(80 \%)$; (b) $\mathrm{CBr}_{4}, \mathrm{PPh}_{3}, \mathrm{CH}_{2} \mathrm{Cl}_{2},-78{ }^{\circ} \mathrm{C}, 2 \mathrm{~h}$ (84\%); (c) $\mathrm{Me}_{3} \mathrm{SnSnMe}_{3}, \mathrm{Pd}\left(\mathrm{PPh}_{3}\right)_{4}, \mathrm{LiCl}$, THF, $60{ }^{\circ} \mathrm{C}, 3.5 \mathrm{~h}(79 \%)$; (d) $\mathrm{Pd}_{2} \mathrm{dba}_{3}$, (fur) ${ }_{3} \mathrm{P}$, toluene, reflux, $4 \mathrm{~h}$ (71\%); (e) $t$-BuLi, THF, $-78{ }^{\circ} \mathrm{C}, 10 \mathrm{~min}(42 \%)$; (f) TBAF, THF, rt, $1 \mathrm{~h}$ $(88 \%)$.

The further conversion of 23 into himbacine analogues 14a, 14b, 15a and 15b is shown in Scheme 4. First the alcohol 23 was converted into the corresponding acrylate $\mathbf{2 4}$ using acryloyl chloride and diisopropylethylamine (DIPEA) in dichloromethane (77\% yield). The Diels-Alder reaction of 24 required high temperatures $\left(185{ }^{\circ} \mathrm{C}\right.$, toluene) and the presence of both an antioxidant (TEMPO) and a base (DIPEA). ${ }^{42}$ After $24 \mathrm{~h}$ a mixture of the two stereoisomeric vinylic bromides $25 \mathbf{a}$ and $\mathbf{2 5 b}$ was obtained in $79 \%$ yield. 


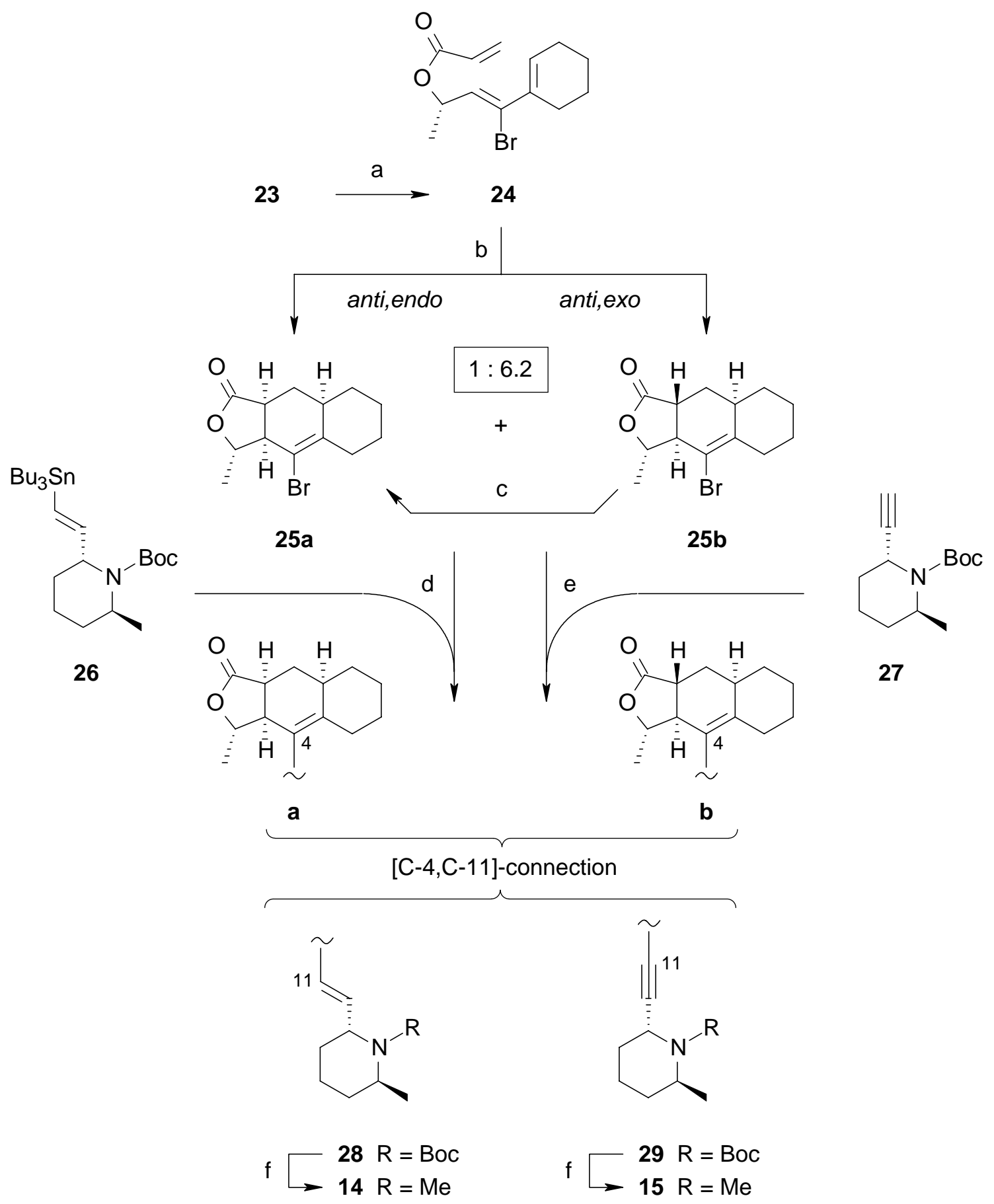

Scheme 4. (a) $\mathrm{CH}_{2}=\mathrm{CHCOCl}$, DIPEA, $\mathrm{CH}_{2} \mathrm{Cl}_{2},-50{ }^{\circ} \mathrm{C}, 10$ min (77\%); (b) TEMPO, DIPEA, toluene, $185^{\circ} \mathrm{C}, 24 \mathrm{~h}(79 \%)$; (c) NaH, THF, rt, $2 \mathrm{~h}\left(82 \%\right.$ ); (d) $\mathrm{Pd}_{2} \mathrm{dba}_{3}$, (fur) ${ }_{3} \mathrm{P}$, DIPEA, toluene, reflux, 2 h (25a $\rightarrow$ 28a: 80\%; 25b $\rightarrow$ 28b: 77\%); (e) $\mathrm{Pd}\left(\mathrm{PPh}_{3}\right)_{2}(\mathrm{OAc})_{2}, \mathrm{Et}_{3} \mathrm{~N}, \mathrm{CH}_{3} \mathrm{CN}$, reflux, $1 \mathrm{~h}$ (25a $\rightarrow$ 29a: 76\%; 25b $\rightarrow$ 29b: 73\%); (f) TFA, $\mathrm{CH}_{2} \mathrm{Cl}_{2}$, rt, 1 h; $37 \%$ aqueous $\mathrm{H}_{2} \mathrm{CO}, \mathrm{NaBH}_{3} \mathrm{CN}$, $\mathrm{CH}_{3} \mathrm{CN}$, rt, 1 h (14a: 81\%; 14b: 80\%; 15a: 75\%; 15b: 78\%). 
The expected anti,exo-adduct (25b) predominated (ratio 25a:25b = 1:6.2). The structural assignment of both adducts follows from the X-ray crystal structure determination of $\mathbf{2 5 b}$ and from the observation that upon basic treatment the trans-fused lactone in $\mathbf{2 5 b}$ is isomerized into the more stable cis-fused adduct 25a. ${ }^{33 a}$ In line with this experimental result, force field calculations indicate a relative steric energy difference of $9.9 \mathrm{~kJ} \mathrm{~mol}^{-1}$ in favour of $25 \mathbf{a}^{43}$

The transformation of 25a and of 25b into the desired analogues 14a, 15a and 14b, 15b, respectively, involves palladium catalyzed cross-coupling reactions. The Stille reaction between bromides 25a and 25b, and the vinyltributylstannane 26 using tris(dibenzylideneacetone)dipalladium(0) and tri-2-furylphosphine in the presence of DIPEA (toluene, reflux) afforded dienes 28a (80\% yield) and 28b (77\% yield), respectively. The synthesis of vinylstannane 26 proceeded by reaction of a higher order tributyltincuprate derivative, obtained from copper(I) cyanide, $n$-butyllithium and tributyltinhydride, ${ }^{44}$ with the known terminal alkyne $27(80 \%$ yield). ${ }^{28}$ The Sonogashira coupling involved reaction of the same bromides 25a and 25b with alkyne 27 (bis(triphenylphosphine)palladium(II) acetate, triethylamine in acetonitrile) and afforded enynes 29a (76\% yield) and 29b (73\% yield), respectively. ${ }^{45}$ It is worth noting that the above conditions are the result of thorough experimentation. ${ }^{46}$ The final conversion of the $N$-Boc derivatives 28a, 28b, 29a and 29b into the corresponding $N$-methylated analogues 14a, 14b, 15a, and 15b proceeded in two steps: after acidic removal of the Boc protective group (trifluoroacetic acid, dichloromethane), the resulting crude secondary amines were treated with $37 \%$ aqueous formaldehyde and sodium cyanoborohydride in acetonitrile to yield 14a (81\% yield), 14b (80\% yield), 15a (75\% yield) and $\mathbf{1 5 b}$ (78\% yield), respectively.

At this point it is interesting to focus in more detail on the stereochemical outcome of the Diels-Alder reaction of the pentadienyl acrylate system as present in precursor $24{ }^{47}$ Very recently a few related cases have been reported in considerable detail. The relevant transformations dealing with C-1 substituted derivatives are depicted in Scheme 5. The reaction of the double activated dienophile substrates was studied by Paddon-Row and Sherburn: ${ }^{48}$ (i) the more reactive maleate gave isomers $\mathbf{a}$ and $\mathbf{b}$ in the same ratio (1:6.1) as observed in the reaction of 24; (ii) the fumarate led to the formation of the three isomers $\mathbf{a}, \mathbf{b}$ and $\mathbf{c}$ with a distinct preference for the anti,exo-adduct $\mathbf{b}$. The cycloaddition of the acrylate studied by White and Snyder (iii) required harsher reaction conditions and led to a mixture of the $\mathbf{a}$, $\mathbf{b}$ and $\mathbf{c}$ stereoisomers; ${ }^{49}$ although the observed stereoselectivity was poor, the anti,exo-adduct $\mathbf{b}$ again predominated. Lastly, the cycloaddition of a C-3 bromine substituted pentadienyl acrylate, described by Paddon-Row and Sherburn (iv) leads to the corresponding stereoisomers a and $b$, with again a clear preference for the anti,exo-adduct $\mathbf{b}{ }^{35}$ Interestingly in the previous studies elaborate DFT calculations have corroborated the experimental results. Since the cycloadditions were shown to proceed under kinetic control, the relative energies of the different transition states were calculated. Our result is almost identical to the one observed in (iv). This is not really surprising in view of the presumed determining influence of the steric interference, related to ${ }^{1,3} \mathrm{~A}$-strain, ${ }^{50}$ between the C-1 alkyl and C-3 bromine substituents. The latter substituent has been termed a "steric directing group" by Paddon-Row and Sherburn in this particular context. ${ }^{35}$ 


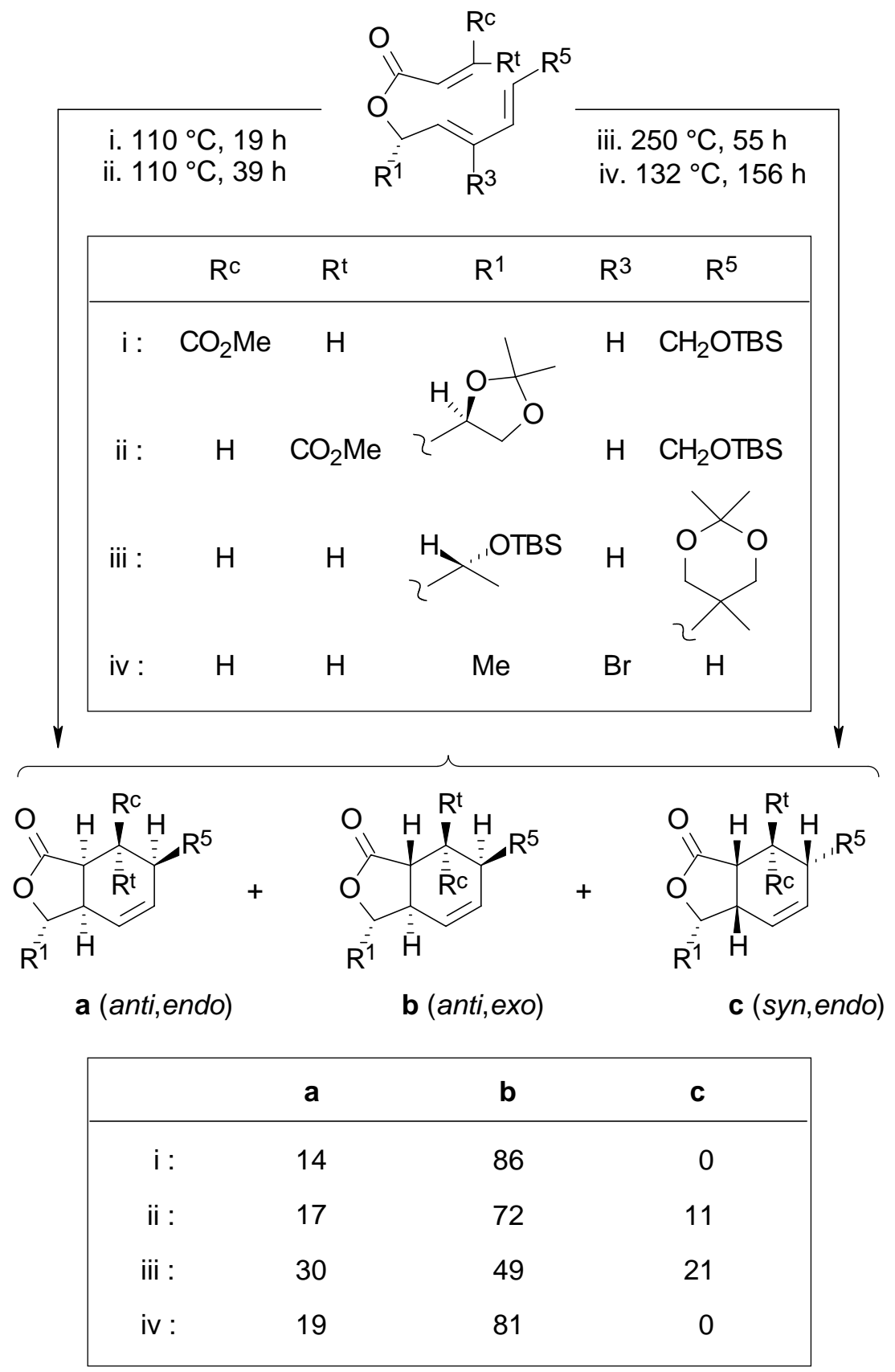

\section{Scheme 5}

\section{Binding affinity studies}

The binding studies of synthetic (+)-himbacine 1 and of the four derivatives 14a, 14b, 15a and 15b for the four muscarine receptor subtypes were carried out by analysis of competition experiments with $\left[{ }^{3} \mathrm{H}\right]-\mathrm{N}$-methylscopolamine (NMS) at $25{ }^{\circ} \mathrm{C}$ in a $50 \mathrm{mM}$ sodium phosphate/ $2 \mathrm{mM}$ magnesium chloride buffer $(\mathrm{pH} 7.4) .{ }^{51}$ The $\left[{ }^{3} \mathrm{H}\right]-\mathrm{NMS}$ saturation curves in each cell line were compatible with recognition of a single receptor subtype. In the present set of experiments, 
the $\left[{ }^{3} \mathrm{H}\right]$-NMS $\mathrm{K}_{\mathrm{D}}$ values were $0.26,0.50,0.42$ and $0.18 \mathrm{nM}$ at $\mathrm{M}_{1}, \mathrm{M}_{2}, \mathrm{M}_{3}$ and $\mathrm{M}_{4}$ muscarinic receptors, respectively. Representative competition curves are included in the supporting information section. The corresponding $\mathrm{pK}_{\mathrm{i}}$ values are given in Table 2.

Table 2. $\mathrm{K}_{\mathrm{i}}$ values $(\mathrm{nM})$ and $\mathrm{pK}_{\mathrm{i}}$ values (between parentheses) at cloned $\mathrm{CHO}$ cells expressing $\mathrm{hM}_{1}, \mathrm{hM}_{2}, \mathrm{hM}_{3}$, and $\mathrm{hM}_{4}$ muscarine receptors ${ }^{\mathrm{a}}$

\begin{tabular}{crrrr}
\hline Compound & $\mathrm{hM}_{1}$ & $\mathrm{hM}_{2}$ & \multicolumn{1}{c}{$\mathrm{hM}_{3}$} & \multicolumn{1}{c}{$\mathrm{hM}_{4}$} \\
\hline $\mathbf{1}^{\mathrm{b}}$ & $160(6.80)$ & $4.7(8.33)$ & $100(6.98)$ & $8.7(8.06)$ \\
14a & $700(6.16)$ & $1400(5.87)$ & $2500(5.61)$ & $1500(5.81)$ \\
14b & $2500(5.61)$ & $2600(5.59)$ & $6500(5.19)$ & $6000(5.22)$ \\
15a & $1800(5.74)$ & $100(7.00)$ & $1700(5.77)$ & $270(6.57)$ \\
15b & $8500(5.07)$ & $2600(5.59)$ & $17000(4.77)$ & $3600(5.44)$ \\
\hline
\end{tabular}

a Since the distribution of the $\mathrm{K}_{\mathrm{i}}$ values is lognormal, $\mathrm{pK}_{\mathrm{i}}$ values, $-\log \left(\mathrm{K}_{\mathrm{i}}\right.$ concentration units), are also mentioned; the calculated s.e.m. values vary between \pm 0.01 and $\pm 0.40{ }^{\mathrm{b}}$ synthetic $(+)$ himbacine, see reference 24.

The results of the binding studies indicate that all analogues possess a lower affinity for each receptor subtype when compared with himbacine. Analogue 15a shows an 18-fold selectivity for the $M_{2}$ relative to the $M_{1}$ receptor. It is interesting to note that the structure of 15a involves an acetylenic connecting bridge instead of the natural $(E)$-ethylenic moiety.

\section{Conclusions}

We have developed a concise convergent approach towards the synthesis of 4,4adehydrohimbacine derivatives. The key step in the synthesis involves an intramolecular Diels-Alder reaction of a substituted pentadienyl acrylate (24), which afforded with good stereoselectivity the trans-fused lactone bromide 25b, the adduct resulting from the expected preferred anti,exo-addition. Subsequent attachment of the piperidine D-ring involved Stille (vinylstannane 26) and Sonogashira (alkyne 27) coupling reactions.

\section{Experimental Section}

General Procedures. All air sensitive reactions were run under $\mathrm{Ar}$ or $\mathrm{N}_{2}$ atmosphere and reagents were added through septa using oven dried syringes. $\mathrm{Et}_{2} \mathrm{O}$ and $\mathrm{THF}$ were distilled from benzophenone ketyl prior to use. $N, N$-Diisopropylethylamine (DIPEA), $\mathrm{Et}_{3} \mathrm{~N}, \mathrm{CH}_{3} \mathrm{CN}$ and HMPA were distilled from $\mathrm{CaH}_{2}$ and $\mathrm{CH}_{2} \mathrm{Cl}_{2}$ was distilled from $\mathrm{P}_{2} \mathrm{O}_{5}$. TLC were run on glass plates pre-coated with silica gel (Merck, 60F254). Column chromatography was performed on 
silica gel (Merck, 230-400 mesh) and HPLC separations were performed on Bio-Sil D 90-10, 10$\mu \mathrm{m}$ columns (Bio-Rad) of $1 \times 25 \mathrm{~cm}$ and $2.2 \times 25 \mathrm{~cm} .{ }^{1} \mathrm{H}$ NMR chemical shifts are reported in ppm $(\delta)$ relative to $\mathrm{CDCl}_{3}(7.26 \mathrm{ppm})$ or $\mathrm{C}_{6} \mathrm{D}_{6}(7.16 \mathrm{ppm})$ as an internal reference. ${ }^{13} \mathrm{C} \mathrm{NMR}$ chemical shifts are reported in ppm $(\delta)$ relative to $\mathrm{CDCl}_{3}(77.16 \mathrm{ppm})$ or $\mathrm{C}_{6} \mathrm{D}_{6}(128.06 \mathrm{ppm})$ as an internal reference. Mass spectra were recorded at $70 \mathrm{eV}$.

(Z,3S)-1-Bromo-3-(tert-butyldimethylsilyl)oxy-1-(cyclohex-1-enyl)but-1-ene (21). To a solution of tris(dibenzylideneacetone)dipalladium $(0)\left(\mathrm{Pd}_{2} \mathrm{dba}_{3}, 0.372 \mathrm{~g}, 0.4 \mathrm{mmol}\right)$ and tri-2furylphosphine $(0.404 \mathrm{~g}, 1.7 \mathrm{mmol})$ in toluene $(35 \mathrm{~mL})$ was added dibromide $18(2.0 \mathrm{~g}, 5.8$ $\mathrm{mmol})$. After stirring at $\mathrm{rt}$ for $15 \mathrm{~min}$, tin derivative 20 (1.5 g, $6.1 \mathrm{mmol})$ was dropwise added and the reaction mixture was refluxed for $4 \mathrm{~h}$ (color change from yellow to dark red-brown). The reaction mixture was cooled to $\mathrm{rt}$, toluene was evaporated under reduced pressure and the residue was purified by column chromatography on silica gel (isooctane/EtOAc 9:1) to give 21 (1.42 g, 71\%) as a light-yellow oil: $\mathrm{R}_{\mathrm{f}}$ (isooctane/EtOAc 9:1) 0.7; $[\alpha]_{\mathrm{D}}^{20}-2.7$ (c 1.000, $\left.\mathrm{CHCl}_{3}\right)$; IR $(\mathrm{KBr}$ film) $\vee 2929,2886,2857,1255,1140,1078,998,834,776 \mathrm{~cm}^{-1} ;{ }^{1} \mathrm{H}$ NMR $\left(500 \mathrm{MHz}, \mathrm{CDCl}_{3}\right) \delta$ $6.28(1 \mathrm{H}, \mathrm{br}$ s), $5.92(1 \mathrm{H}, \mathrm{d}, J=7.2 \mathrm{~Hz}), 4.79(1 \mathrm{H}, \mathrm{dq}, J=6.5,6.5 \mathrm{~Hz}), 2.24-2.18(4 \mathrm{H}, \mathrm{m}), 1.71-$ $1.66(2 \mathrm{H}, \mathrm{m}), 1.61-1.55(2 \mathrm{H}, \mathrm{m}), 1.25(3 \mathrm{H}, \mathrm{d}, J=6.3 \mathrm{~Hz}), 0.89(9 \mathrm{H}, \mathrm{s}), 0.08(3 \mathrm{H}, \mathrm{s}), 0.06(3 \mathrm{H}$, s); ${ }^{13} \mathrm{C} \mathrm{NMR/DEPT}\left(50 \mathrm{MHz}, \mathrm{CDCl}_{3}\right) \delta 134.0(\mathrm{C}), 132.4(\mathrm{CH}), 130.9(\mathrm{CH}), 125.8(\mathrm{C}), 70.1$ $(\mathrm{CH}), 26.9\left(\mathrm{CH}_{2}\right), 25.9\left(\mathrm{CH}_{3}\right), 25.8\left(\mathrm{CH}_{2}\right), 23.3\left(\mathrm{CH}_{2}\right), 22.8\left(\mathrm{CH}_{2}\right), 22.0\left(\mathrm{CH}_{2}\right), 18.2(\mathrm{C}),-4.5$ $\left(\mathrm{CH}_{3}\right),-4.8\left(\mathrm{CH}_{3}\right)$; MS m/z 288 (28), 287 (30), 273 (1), 245 (1), 225 (1), 183 (100), 181 (100), 139 (34), 137 (34), 91 (46), 75 (78), 73 (78). Anal. Calcd for $\mathrm{C}_{16} \mathrm{H}_{29}$ BrOSi: C, 55.64; H, 8.46. Found: C, 55.81; H, 8.57.

(Z,2S)-4-tert-Butyldimethylsilyl-4-(cyclohex-1-enyl)but-3-en-2-ol (22). To a solution of bromide 21 (25 mg, $0.072 \mathrm{mmol})$ in dry THF $(0.9 \mathrm{~mL})$ at $-78{ }^{\circ} \mathrm{C}$ was dropwise added $t$-BuLi $(1.7 \mathrm{M}$ in pentane, $0.053 \mathrm{~mL}, 0.09 \mathrm{mmol})$. After stirring for $10 \mathrm{~min}$, the yellow-colored reaction mixture was poured into water $(5 \mathrm{~mL})$. The aqueous phase was extracted with $\mathrm{Et}_{2} \mathrm{O}$ and the combined organic layers were dried over anhydrous $\mathrm{MgSO}_{4}$. The solvent was removed under reduced pressure and the residue was purified by HPLC on silica gel ( $n$-pentane/EtOAc 9:1) to afford pure 22 (8 mg, 42\%): $\mathrm{R}_{\mathrm{f}}$ (isooctane/EtOAc 9:1) 0.15; IR ( $\mathrm{KBr}$ film) v 2956, 2828, 2856, 1249, 1053, 834, 823, $765 \mathrm{~cm}^{-1} ;{ }^{1} \mathrm{H}$ NMR $\left(500 \mathrm{MHz}, \mathrm{CDCl}_{3}\right) \delta 5.92(1 \mathrm{H}, \mathrm{d}, J=9.8 \mathrm{~Hz}), 5.23(1 \mathrm{H}$, br s), $4.43(1 \mathrm{H}, \mathrm{dq}, J=9.8,6.1 \mathrm{~Hz}), 2.04-2.01(2 \mathrm{H}, \mathrm{m}), 1.24(3 \mathrm{H}, \mathrm{d}, J=6.1 \mathrm{~Hz}), 0.94(9 \mathrm{H}, \mathrm{s}), 0.13$ $(3 \mathrm{H}, \mathrm{s}), 0.09(3 \mathrm{H}, \mathrm{s}) ;{ }^{13} \mathrm{C}$ NMR/DEPT $\left(50 \mathrm{MHz}, \mathrm{CDCl}_{3}\right) \delta 146.7(\mathrm{CH}), 145.4(\mathrm{C}), 143.4(\mathrm{C})$, 121.4 (CH), $67.7(\mathrm{CH}), 30.7\left(\mathrm{CH}_{2}\right), 27.6\left(\mathrm{CH}_{3}\right), 25.2\left(\mathrm{CH}_{2}\right), 23.1\left(\mathrm{CH}_{2}\right), 23.0\left(\mathrm{CH}_{3}\right), 22.2\left(\mathrm{CH}_{2}\right)$, 17.7 (C), -2.6 ( $\left.\mathrm{CH}_{3}\right),-2.7\left(\mathrm{CH}_{3}\right)$; MS m/z 209 (2), 191 (1), 133 (14), 105 (3), 91 (5), 75 (100).

(Z,2S)-4-Bromo-4-(cyclohex-1-enyl)but-3-en-2-ol (23). Tetrabutylammonium fluoride (TBAF, $1 \mathrm{M}$ in THF, $5.43 \mathrm{~mL}, 5.43 \mathrm{mmol})$ was dropwise added to a solution of bromide $21(1.5 \mathrm{~g}, 4.34$ $\mathrm{mmol})$ in dry THF (12 mL) at rt. After stirring for $1 \mathrm{~h}$, the reaction mixture was concentrated under reduced pressure and the residue was purified by column chromatography on silica gel (isooctane/EtOAc 95:5 to 8:2) to give alcohol $23(0.882 \mathrm{~g}, 88 \%)$ as a colorless oil: $\mathrm{R}_{\mathrm{f}}$ (isooctane/EtOAc 8:2) 0.1; $[\alpha]^{20}{ }_{\mathrm{D}}-20.1$ (c 0.990, $\left.\mathrm{CHCl}_{3}\right)$; IR (KBr film) v 3322, 2970, 2928, 2858, 
$2830,1634,1613,1448,1436,1366,1183,1169,1138,1063,880,801 \mathrm{~cm}^{-1} ;{ }^{1} \mathrm{H}$ NMR $(500$ $\left.\mathrm{MHz}, \mathrm{CDCl}_{3}\right) \delta 6.34(1 \mathrm{H}, \mathrm{t}, J=4.1 \mathrm{~Hz}), 5.95(1 \mathrm{H}, \mathrm{d}, J=7.3 \mathrm{~Hz}), 4.84(1 \mathrm{H}, \mathrm{dq}, J=6.6,6.6 \mathrm{~Hz})$, 2.25-2.18 (4H, m), $1.79(1 \mathrm{H}, \mathrm{br} \mathrm{s}), 1.70-1.66(2 \mathrm{H}, \mathrm{m}), 1.60-1.56(2 \mathrm{H}, \mathrm{m}), 1.33(3 \mathrm{H}, \mathrm{d}, J=6.4$ $\mathrm{Hz}) ;{ }^{13} \mathrm{C}$ NMR/DEPT $\left(50 \mathrm{MHz}, \mathrm{CDCl}_{3}\right) \delta 133.9(\mathrm{C}), 131.7(\mathrm{CH}), 130.7(\mathrm{CH}), 128.7(\mathrm{C}), 68.6$ (CH), $26.9\left(\mathrm{CH}_{2}\right), 25.9\left(\mathrm{CH}_{2}\right), 22.7\left(\mathrm{CH}_{2}\right), 22.2\left(\mathrm{CH}_{3}\right), 21.9\left(\mathrm{CH}_{2}\right) ; \mathrm{MS} \mathrm{m} / \mathrm{z} 230(1)\left[\mathrm{M}^{+}-\mathrm{H}\right]$, 215 (1), 151 (9), 133 (7), 123 (1), 107 (7), 93 (18), 91 (18), 79 (17), 67 (12), 43 (100). Anal. Calcd for $\mathrm{C}_{10} \mathrm{H}_{15} \mathrm{BrO}$ : C, 51.97; H, 6.54. Found: C, 52.48; H, 6.77.

(Z,2S)-2-[4-Bromo-4-(cyclohex-1-enyl)]but-3-enyl Acrylate (24). To a solution of alcohol 23 $(0.85 \mathrm{~g}, 3.68 \mathrm{mmol})$ in dry dichloromethane $(16 \mathrm{~mL})$ at $-50^{\circ} \mathrm{C}$ were added acryloyl chloride $(0.6$ $\mathrm{mL}, 7.36 \mathrm{mmol})$ and DIPEA $(1.28 \mathrm{~mL}, 7.36 \mathrm{mmol})$. Stirring was continued for $10 \mathrm{~min}$ at $-50^{\circ} \mathrm{C}$ and the reaction mixture was poured into a saturated aqueous $\mathrm{NH}_{4} \mathrm{Cl}$ solution $(10 \mathrm{~mL})$. The aqueous phase was extracted with dichloromethane $(2 \times)$ and the combined organic layers were dried over anhydrous $\mathrm{MgSO}_{4}$. The solvent was removed under reduced pressure and the residue was purified by column chromatography on silica gel (isooctane/EtOAc 9:1) to give ester 24 $(0.81 \mathrm{~g}, 77 \%)$ as a light-yellow oil: $\mathrm{R}_{\mathrm{f}}$ (isooctane/EtOAc 9:1) $0.43 ;[\alpha]^{20}{ }_{\mathrm{D}}-9.75$ (c 0.120 , $\mathrm{CHCl}_{3}$ ); IR (KBr film) v 2931, 2860, 1726, 1636, 1618, 1404, 1294, 1269, 1193, 1150, 1050, 921, 876, $809 \mathrm{~cm}^{-1} ;{ }^{1} \mathrm{H}$ NMR $\left(500 \mathrm{MHz}, \mathrm{CDCl}_{3}\right) \delta 6.41(1 \mathrm{H}, \mathrm{dd}, J=1.4,17.3 \mathrm{~Hz}), 6.37(1 \mathrm{H}, \mathrm{t}, J$ $=4.1 \mathrm{~Hz}), 6.11(1 \mathrm{H}, \mathrm{dd}, J=10.4,17.3 \mathrm{~Hz}), 5.95(1 \mathrm{H}, \mathrm{d}, J=7.5 \mathrm{~Hz}), 5.87(1 \mathrm{H}, \mathrm{dq}, J=6.7,6.7$ $\mathrm{Hz}), 5.82(1 \mathrm{H}, \mathrm{dd}, J=1.4,10.4 \mathrm{~Hz}), 2.24(2 \mathrm{H}, \mathrm{m}), 2.19(2 \mathrm{H}, \mathrm{m}), 1.70-1.53(4 \mathrm{H}, \mathrm{m}), 1.39(3 \mathrm{H}, \mathrm{d}$, $J=6.4 \mathrm{~Hz}) ;{ }^{13} \mathrm{C}$ NMR/DEPT $\left(50 \mathrm{MHz}, \mathrm{CDCl}_{3}\right) \delta 165.3(\mathrm{C}), 133.7(\mathrm{C}), 132.2(\mathrm{CH}), 130.7(\mathrm{CH})$, $129.7(\mathrm{C}), 128.6(\mathrm{CH}), 126.6(\mathrm{CH}), 72.0(\mathrm{CH}), 26.8\left(\mathrm{CH}_{2}\right), 25.9\left(\mathrm{CH}_{2}\right), 22.7\left(\mathrm{CH}_{2}\right), 21.9\left(\mathrm{CH}_{2}\right)$, $19.7\left(\mathrm{CH}_{3}\right) ; \mathrm{MS} \mathrm{m} / \mathrm{z} 285$ (1), 241 (1), 229 (1), 214 (3), 212 (3), 205 (4), 151 (9), 133 (25), 105 (17), 91 (22), 77 (16), 55 (100). Anal. Calcd for $\mathrm{C}_{13} \mathrm{H}_{17} \mathrm{BrO}_{2}$ : C, 54.75; H, 6.01. Found: $\mathrm{C}, 55.89$; H, 6.25 .

(3S,3aR,8aR,9aS)-4-Bromo-3-methyl-3a,5,6,7,8,8a,9,9a-octahydro-3H-naphtho[2,3-c]furan1-one (25a) and (3S,3aR,8aR,9aR)-4-Bromo-3-methyl-3a,5,6,7,8,8a,9,9a-octahydro-3Hnaphtho[2,3-c]furan-1-one (25b). A mixture of ester 24 (0.25 g, $0.88 \mathrm{mmol})$, 2,2,6,6-tetramethyl-1-piperidinyloxy free radical (TEMPO, $10 \mathrm{mg}$ ) and a drop of DIPEA in toluene $(20 \mathrm{~mL})$ was flushed with Ar and heated in a sealed metal tube at $185^{\circ} \mathrm{C}$ for $24 \mathrm{~h}$. After cooling to rt, the reaction mixture was passed through a short silica gel column eluted with isooctane/EtOAc 3:1 $(50 \mathrm{~mL})$. The solvents were removed under reduced pressure and the mixture was separated by HPLC on silica gel (isooctane/EtOAc 10:1) to yield Diels-Alder adducts 25a (0.028 g, 11\%) as a colorless oil and $25 \mathrm{~b}(0.17 \mathrm{~g}, 68 \%)$ as white crystals, next to unreacted $24(0.02 \mathrm{~g}, 8 \%)$. 25a: $\mathrm{R}_{\mathrm{f}}$ (isooctane/EtOAc 4:1) 0.38; $[\alpha]^{20}{ }_{\mathrm{D}}+16.1\left(\mathrm{c} 1.320, \mathrm{CHCl}_{3}\right)$; IR ( $\mathrm{KBr}$ film) $\vee 2929,2855,1778$, 1448, 1384, 1313, 1196, 1064, 957, 934, $769 \mathrm{~cm}^{-1} ;{ }^{1} \mathrm{H}$ NMR $\left(500 \mathrm{MHz}, \mathrm{CDCl}_{3}\right) \delta 4.56(1 \mathrm{H}, \mathrm{dq}$, $J=7.7,6.2 \mathrm{~Hz}), 3.02(1 \mathrm{H}, \mathrm{m}), 2.96(1 \mathrm{H}, \mathrm{dd}, J=7.8,7.8 \mathrm{~Hz}), 2.79(1 \mathrm{H}, \mathrm{ddd}, J=5.1,7.8,11.8$ $\mathrm{Hz}), 2.09(1 \mathrm{H}, \mathrm{ddd}, J=5.3,5.3,13.6 \mathrm{~Hz}), 1.89-1.76(4 \mathrm{H}, \mathrm{m}), 1.64(3 \mathrm{H}, \mathrm{d}, J=6.2 \mathrm{~Hz}), 1.56(1 \mathrm{H}$, $\mathrm{m}), 1.42-1.20(2 \mathrm{H}, \mathrm{m}), 1.05(1 \mathrm{H}, \mathrm{ddt}, J=3.6,12.7,12.7 \mathrm{~Hz}) ;{ }^{13} \mathrm{C}$ NMR/DEPT $\left(50 \mathrm{MHz}, \mathrm{CDCl}_{3}\right)$

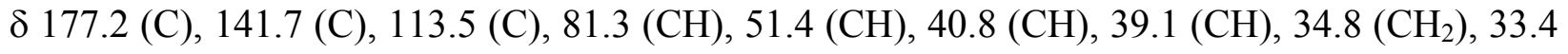
$\left(\mathrm{CH}_{2}\right), 29.0\left(\mathrm{CH}_{2}\right), 25.3\left(\mathrm{CH}_{2}\right), 25.0\left(\mathrm{CH}_{2}\right), 23.2\left(\mathrm{CH}_{3}\right) ; \mathrm{MS} \mathrm{m} / \mathrm{z} 285$ (7) $\left[\mathrm{M}^{+}\right], 241$ (4), 239 (4), 
214 (44), 212 (43), 172 (23), 170 (23), 149 (4), 133 (17), 105 (15), 91 (100), 77 (25), 43 (26); ESMS m/z 302 and $304\left[\mathrm{M}+\mathrm{NH}_{3}\right]^{+}$. Anal. Calcd for $\mathrm{C}_{13} \mathrm{H}_{17} \mathrm{BrO}_{2}$ : C, 54.75; H, 6.01. Found: C, 55.81; H, 6.28. 25b: $\mathrm{R}_{\mathrm{f}}$ (isooctane/EtOAc 4:1) 0.44; $\mathrm{mp} 87^{\circ} \mathrm{C} ;[\alpha]^{20}{ }_{\mathrm{D}}-0.92$ (c 1.090, $\mathrm{CHCl}_{3}$ ); IR $(\mathrm{KBr}$ film $) \vee 2924,2854,1796,1444,1386,1291,1140,1085,1027,962,839,717 \mathrm{~cm}^{-1} ;{ }^{1} \mathrm{H}$ NMR $\left(500 \mathrm{MHz}, \mathrm{CDCl}_{3}\right) \delta 4.39(1 \mathrm{H}, \mathrm{dq}, J=9.7,5.9 \mathrm{~Hz}), 2.96(1 \mathrm{H}, \mathrm{ddd}, J=4.0,4.0,9.4 \mathrm{~Hz})$, $2.67(2 \mathrm{H}, \mathrm{m}), 2.39(1 \mathrm{H}, \mathrm{m}), 1.90-1.68(6 \mathrm{H}, \mathrm{m}), 1.66(3 \mathrm{H}, \mathrm{d}, J=6.0 \mathrm{~Hz}), 1.51-1.40(2 \mathrm{H}, \mathrm{m}), 1.28-$ $1.24(1 \mathrm{H}, \mathrm{m}) ;{ }^{13} \mathrm{C} \mathrm{NMR/DEPT}\left(50 \mathrm{MHz}, \mathrm{CDCl}_{3}\right) \delta 175.0(\mathrm{C}), 143.0(\mathrm{C}), 110.5(\mathrm{C}), 80.5(\mathrm{CH})$, $53.5(\mathrm{CH}), 45.0(\mathrm{CH}), 41.8(\mathrm{CH}), 35.5\left(\mathrm{CH}_{2}\right), 34.0\left(\mathrm{CH}_{2}\right), 28.5\left(\mathrm{CH}_{2}\right), 27.1\left(\mathrm{CH}_{2}\right), 26.5\left(\mathrm{CH}_{2}\right)$, $20.2\left(\mathrm{CH}_{3}\right)$; ESMS m/z 302 and $304\left[\mathrm{M}+\mathrm{NH}_{3}\right]^{+}$. Anal. Calcd for $\mathrm{C}_{13} \mathrm{H}_{17} \mathrm{BrO}_{2}: \mathrm{C}, 54.75 ; \mathrm{H}, 6.01$. Found: C, 54.71; H, 6.16.

Isomerization of $25 \mathbf{b}$ to $25 \mathbf{a}$. To a solution of $\mathbf{2 5 b}(50 \mathrm{mg}, 0.18 \mathrm{mmol})$ in dry THF $(1.25 \mathrm{~mL})$ was added $\mathrm{NaH}(60 \%$ dispersion in mineral oil, $35 \mathrm{mg}, 0.88 \mathrm{mmol})$ in one portion. The reaction mixture was stirred at $\mathrm{rt}$ for $2 \mathrm{~h}$, then poured into a mixture of a saturated aqueous $\mathrm{NH}_{4} \mathrm{Cl}$ solution $(10 \mathrm{~mL})$ and $\mathrm{Et}_{2} \mathrm{O}(10 \mathrm{~mL})$. The aqueous phase was extracted with $\mathrm{Et}_{2} \mathrm{O}(3 \times 10 \mathrm{~mL})$ and the combined extracts were dried over anhydrous $\mathrm{MgSO}_{4}$. After filtration and concentration under reduced pressure, the residue was chromatographed on silica gel (isooctane/EtOAc 8:1) to give 25a (41 mg, 82\%) as a colorless oil, identical to the minor isomer obtained in the above Diels-Alder reaction of 24.

tert-Butyl (2S,6R)-6-[(E)-2-(Tributylstannyl)ethenyl]-2-methylpiperidinecarboxylate (26). To a solution of $\mathrm{CuCN}(0.20 \mathrm{~g}, 2.24 \mathrm{mmol})$ in dry $\mathrm{THF}(6 \mathrm{~mL})$ at $-78{ }^{\circ} \mathrm{C}$ under Ar was dropwise added $n$-BuLi $(2.5 \mathrm{M}$ in hexanes, $1.91 \mathrm{~mL}, 4.77 \mathrm{mmol})$. After stirring at $-78{ }^{\circ} \mathrm{C}$ for $15 \mathrm{~min}$, $\mathrm{Bu}_{3} \mathrm{SnH}$ (1.39 g, $4.77 \mathrm{mmol}$ ) was dropwise added to the reaction mixture (color change to light yellow). After stirring at $-78^{\circ} \mathrm{C}$ for $10 \mathrm{~min}$, alkyne $27(0.50 \mathrm{~g}, 2.24 \mathrm{mmol})$ in dry THF $(2 \mathrm{~mL})$ was dropwise added (color change to light orange). After stirring at $-78{ }^{\circ} \mathrm{C}$ for an additional 10 min, the reaction mixture was poured into an aqueous $\mathrm{NH}_{4} \mathrm{Cl} / \mathrm{NH}_{4} \mathrm{OH}$ buffer solution $(\mathrm{pH}$ 12). The precipitated salts were filtered off using a pad of Celite, the filtrate was dried over anhydrous $\mathrm{MgSO}_{4}$ and the solvents were removed under reduced pressure. The residue was purified by column chromatography on silica gel (isooctane/EtOAc 95:5) followed by HPLC on silica gel (isooctane/EtOAc 98:2) to yield tin derivative $26(0.99 \mathrm{~g}, 86 \%)$ as a colorless oil: $\mathrm{R}_{\mathrm{f}}$ (isooctane/EtOAc 9:1) 0.45; $[\alpha]^{20}{ }_{\mathrm{D}}+48.9$ (c 2.120, $\left.\mathrm{CHCl}_{3}\right)$; IR ( $\mathrm{KBr}$ film) v 2956, 2927, 1692, 1464, 1389, 1374, 1178, 1151, $1112 \mathrm{~cm}^{-1} ;{ }^{1} \mathrm{H}$ NMR (500 MHz, $\left.\mathrm{CDCl}_{3}\right) \delta 5.95(2 \mathrm{H}, \mathrm{s}), 4.43(1 \mathrm{H}$, br s), $4.06(1 \mathrm{H}, \mathrm{m}), 1.97-1.85(3 \mathrm{H}, \mathrm{m}), 1.61-1.51(3 \mathrm{H}, \mathrm{m}), 1.50-1.42(6 \mathrm{H}, \mathrm{m}), 1.44(9 \mathrm{H}, \mathrm{s}), 1.33-$ $1.25(6 \mathrm{H}, \mathrm{m}), 1.24(3 \mathrm{H}, \mathrm{d}, J=6.6 \mathrm{~Hz}), 0.94-0.86(15 \mathrm{H}, \mathrm{m}) ;{ }^{13} \mathrm{C} \mathrm{NMR} / \mathrm{DEPT}\left(50 \mathrm{MHz}, \mathrm{CDCl}_{3}\right) \delta$ $155.4(\mathrm{C}), 150.1(\mathrm{CH}), 125.3(\mathrm{CH}), 78.8(\mathrm{C}), 55.4(\mathrm{CH}), 47.0(\mathrm{CH}), 29.1\left(\mathrm{CH}_{2}\right), 28.4\left(\mathrm{CH}_{3}\right), 27.2$ $\left(\mathrm{CH}_{2}\right), 26.2\left(\mathrm{CH}_{2}\right), 25.0\left(\mathrm{CH}_{2}\right), 20.8\left(\mathrm{CH}_{3}\right), 13.7\left(\mathrm{CH}_{3}\right), 13.6\left(\mathrm{CH}_{2}\right), 9.4\left(\mathrm{CH}_{2}\right) ; \mathrm{MS} \mathrm{m} / \mathrm{z} 514$ (1) $\left[\mathrm{M}^{+}\right], 458$ (8), 402 (22), 356 (1), 327 (1), 251 (6), 242 (3), 177 (14), 121 (15), 57 (100). Anal. Calcd for $\mathrm{C}_{25} \mathrm{H}_{49} \mathrm{NO}_{2} \mathrm{Sn}$ : C, 58.38; H, 9.60; N, 2.72. Found: C, 59.20; H, 9.68; N, 2.72. 


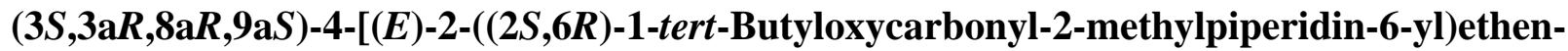
yl]-3-methyl-3a,5,6,7,8,8a,9,9a-octahydro-3H-naphtho[2,3-c]furan-1-one (28a). To a mixture of tris(dibenzylideneacetone)dipalladium(0) $\left(\mathrm{Pd}_{2} \mathrm{dba}_{3}, 8 \mathrm{mg}, 0.009 \mathrm{mmol}\right)$, tri-2-furylphosphine (12 mg, $0.052 \mathrm{mmol})$ and DIPEA $(0.05 \mathrm{~mL}, 0.28 \mathrm{mmol})$ in toluene $(2.5 \mathrm{~mL})$ was added bromide 25a (25 mg, $0.088 \mathrm{mmol})$ followed by tin derivative $26(68 \mathrm{mg}, 0.13 \mathrm{mmol})$. The mixture was flushed 3 times with Ar and then refluxed under Ar for $2 \mathrm{~h}$ (color change to brown). The reaction mixture was cooled to rt, diluted with $n$-pentane $(5 \mathrm{~mL})$ and filtered through a pad of silica gel, which was rinsed with isooctane/EtOAc 3:1 $(20 \mathrm{~mL})$. After concentration under reduced pressure, the residue was purified by HPLC on silica gel (isooctane/EtOAc 5:1) to afford 28a (36 $\mathrm{mg}, 80 \%$ ) as a colorless oil: $\mathrm{R}_{\mathrm{f}}$ (isooctane/EtOAc 4:1) $0.23 ;[\alpha]^{20}{ }_{\mathrm{D}}+15.2$ (c $0.250, \mathrm{CHCl}_{3}$ ); IR $(\mathrm{KBr}$ film $) \vee 2972,2931,2856,1771,1682,1454,1391,1364,1316,1267,1251,1176,1114$, 1089, 1064, 956, $736 \mathrm{~cm}^{-1} ;{ }^{1} \mathrm{H}$ NMR $\left(500 \mathrm{MHz}, \mathrm{CDCl}_{3}\right) \delta 6.34(1 \mathrm{H}, \mathrm{d}, J=16.0 \mathrm{~Hz}), 5.61(1 \mathrm{H}$, $\mathrm{dd}, J=5.8,16.0 \mathrm{~Hz}), 4.49(1 \mathrm{H}, \mathrm{m}), 4.37(1 \mathrm{H}, \mathrm{dq}, J=7.6,6.3 \mathrm{~Hz}), 4.06(1 \mathrm{H}, \mathrm{m}), 2.94(1 \mathrm{H}, \mathrm{m})$, $2.92(1 \mathrm{H}, \mathrm{m}), 2.68(1 \mathrm{H}, \mathrm{ddd}, J=5.3,7.4,11.3 \mathrm{~Hz}), 2.15-1.15(15 \mathrm{H}, \mathrm{m}), 1.48(3 \mathrm{H}, \mathrm{d}, J=6.2 \mathrm{~Hz})$, $1.44(9 \mathrm{H}, \mathrm{s}), 1.25(3 \mathrm{H}, \mathrm{d}, J=6.6 \mathrm{~Hz}), 1.10(1 \mathrm{H}, \mathrm{ddd}, J=3.7,12.8,25.2 \mathrm{~Hz}) ;{ }^{1} \mathrm{H}$ NMR $(500$ $\left.\mathrm{MHz}, \mathrm{C}_{6} \mathrm{D}_{6}\right) \delta 6.37(1 \mathrm{H}, \mathrm{d}, J=16.0 \mathrm{~Hz}), 5.46(1 \mathrm{H}, \mathrm{dd}, J=6.2,16.0 \mathrm{~Hz}), 4.55(1 \mathrm{H}, \mathrm{m}), 4.15(1 \mathrm{H}$, m), $4.08(1 \mathrm{H}, \mathrm{dq}, J=7.5,6.3 \mathrm{~Hz}), 2.90(1 \mathrm{H}, \mathrm{d}, J=14.4 \mathrm{~Hz}), 2.43(1 \mathrm{H}, \mathrm{t}, 7.7 \mathrm{~Hz}), 2.28(1 \mathrm{H}, \mathrm{m})$, $1.46(9 \mathrm{H}, \mathrm{s}), 1.23(6 \mathrm{H}, \mathrm{d}, J=6.3 \mathrm{~Hz}), 1.80-0.80(16 \mathrm{H}, \mathrm{m}) ;{ }^{13} \mathrm{C} \mathrm{NMR} / \mathrm{DEPT}\left(50 \mathrm{MHz}, \mathrm{CDCl}_{3}\right) \delta$ $179.0(\mathrm{C}), 155.2(\mathrm{C}), 141.1(\mathrm{C}), 132.6(\mathrm{CH}), 126.6(\mathrm{CH}), 122.8(\mathrm{C}), 81.8(\mathrm{CH}), 79.2(\mathrm{C}), 52.9$ $(\mathrm{CH}), 47.2(\mathrm{CH}), 43.9(\mathrm{CH}), 39.0(\mathrm{CH}), 37.7(\mathrm{CH}), 35.8\left(\mathrm{CH}_{2}\right), 30.0\left(\mathrm{CH}_{2}\right), 28.5\left(\mathrm{CH}_{3}\right), 28.1$ $\left(\mathrm{CH}_{2}\right), 27.4\left(\mathrm{CH}_{2}\right), 26.6\left(\mathrm{CH}_{2}\right), 26.3\left(\mathrm{CH}_{2}\right), 26.1\left(\mathrm{CH}_{2}\right), 21.3\left(\mathrm{CH}_{3}\right), 20.6\left(\mathrm{CH}_{3}\right), 13.9\left(\mathrm{CH}_{2}\right)$.

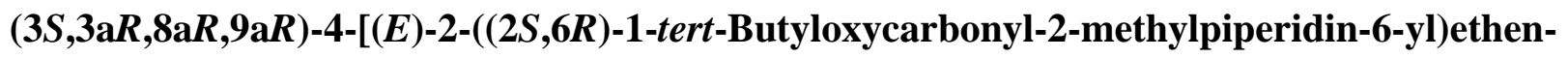
yl]-3-methyl-3a,5,6,7,8,8a,9,9a-octahydro-3H-naphtho[2,3-c]furan-1-one (28b). Bromide 25b was reacted with tin derivative 26 as described above for bromide 25 a to give $\mathbf{2 8 b}(\mathbf{7 7 \%})$ as a waxy solid: $\mathrm{R}_{\mathrm{f}}$ (isooctane/EtOAc 4:1) 0.25; $[\alpha]_{\mathrm{D}}^{20}+56.1$ (c 1.090, $\left.\mathrm{CHCl}_{3}\right)$; IR (KBr film) v 2961, 2933, 2856, 1777, 1686, 1389, 1361, 1279, 1251, 1174, 1112, 1088, 1030, 1002, 959, 916, 882, $767 \mathrm{~cm}^{-1} ;{ }^{1} \mathrm{H} \mathrm{NMR} / \mathrm{COSY}\left(500 \mathrm{MHz}, \mathrm{C}_{6} \mathrm{D}_{6}\right) \delta 5.66(1 \mathrm{H}, \mathrm{d}, J=15.9 \mathrm{~Hz}), 5.40(1 \mathrm{H}, \mathrm{dd}, J=5.7$, $15.9 \mathrm{~Hz}), 4.50(1 \mathrm{H}, \mathrm{dd}, J=4.0,8.9 \mathrm{~Hz}), 4.06(1 \mathrm{H}, \mathrm{m}), 3.95(1 \mathrm{H}, \mathrm{dq}, J=10.0,6.0 \mathrm{~Hz}), 2.84(1 \mathrm{H}$, $\mathrm{d}, J=13.2 \mathrm{~Hz}), 2.14(1 \mathrm{H}, \mathrm{dt}, J=2.8,13.0 \mathrm{~Hz}), 2.03(1 \mathrm{H}, \mathrm{t}, J=11.2 \mathrm{~Hz}), 1.86(1 \mathrm{H}, \mathrm{m}), 1.46(9 \mathrm{H}$, s), $1.42(3 \mathrm{H}, \mathrm{d}, J=6.1 \mathrm{~Hz}), 1.17(3 \mathrm{H}, \mathrm{d}, J=6.6 \mathrm{~Hz}), 1.80-1.00(15 \mathrm{H}, \mathrm{m}) ;{ }^{13} \mathrm{C} \mathrm{NMR} / \mathrm{DEPT}(50$ $\left.\mathrm{MHz}, \mathrm{C}_{6} \mathrm{D}_{6}\right) \delta 175.4(\mathrm{C}), 155.1(\mathrm{C}), 139.6(\mathrm{C}), 136.6(\mathrm{CH}), 127.1(\mathrm{C}), 125.8(\mathrm{CH}), 79.3(\mathrm{CH})$, $78.9(\mathrm{C}), 52.7(\mathrm{CH}), 51.8(\mathrm{CH}), 47.6(\mathrm{CH}), 42.6(\mathrm{CH}), 40.1(\mathrm{CH}), 36.4\left(\mathrm{CH}_{2}\right), 31.4\left(\mathrm{CH}_{2}\right), 29.6$ $\left(\mathrm{CH}_{2}\right), 28.7\left(\mathrm{CH}_{2}\right), 28.6\left(\mathrm{CH}_{3}\right), 27.4\left(\mathrm{CH}_{2}\right), 27.0\left(\mathrm{CH}_{2}\right), 26.6\left(\mathrm{CH}_{2}\right), 20.9\left(2 \mathrm{CH}_{3}\right), 14.3\left(\mathrm{CH}_{2}\right)$; ESMS m/z $881(100)\left[2 \mathrm{M}^{+}+\mathrm{Na}\right], 859(10)\left[2 \mathrm{M}^{+}+\mathrm{H}\right], 673(20), 483(15), 452(20)\left[\mathrm{M}^{+}+\mathrm{Na}\right]$, $430(5)\left[\mathrm{M}^{+}+\mathrm{H}\right], 330(10)$.

(3S,3aR,8aR,9aS)-4-[(E)-2-((2S,6R)-1,2-Dimethylpiperidin-6-yl)ethenyl]-3-methyl-3a,5,6,7, 8,8a,9,9a-octahydro-3H-naphtho[2,3-c]furan-1-one (14a). To a solution of 28a (0.020 g, $0.047 \mathrm{mmol})$ in dichloromethane $(2 \mathrm{~mL})$ was added $\mathrm{CF}_{3} \mathrm{COOH}(0.5 \mathrm{~mL})$. The resulting mixture was stirred at $\mathrm{rt}$ for $1 \mathrm{~h}$ and the solvent was removed under reduced pressure. The residue was dissolved in $\mathrm{CH}_{3} \mathrm{CN}(2 \mathrm{~mL})$ and aqueous formaldehyde $(37 \%, 0.25 \mathrm{~mL})$ followed by $\mathrm{NaBH}_{3} \mathrm{CN}$ 
$(0.04 \mathrm{~g})$ were added. The reaction mixture was stirred at $\mathrm{rt}$ for $1 \mathrm{~h}$, brought to $\mathrm{pH} 7 \mathrm{using}$ $\mathrm{CH}_{3} \mathrm{COOH}$ and stirring was continued for another $2 \mathrm{~h}$. The mixture was concentrated under reduced pressure, the residue was dissolved in dichloromethane $(10 \mathrm{~mL})$ and $\mathrm{NaOH}(2.5 \mathrm{M}$ in water, $5 \mathrm{~mL})$ was added. This mixture was extracted with dichloromethane $(3 \times 10 \mathrm{~mL})$ and the combined extracts were dried over anhydrous $\mathrm{K}_{2} \mathrm{CO}_{3}$. After filtration and concentration, the residue was chromatographed on silica gel (isooctane/acetone $1: 1)$ to give 14a $(0.013 \mathrm{~g}, 81 \%)$ as a colorless oil: $\mathrm{R}_{\mathrm{f}}$ (isooctane/acetone 2:3) 0.28; $[\alpha]_{\mathrm{D}}^{20}-61.5$ (c 1.049, $\mathrm{CHCl}_{3}$ ); UV (MeOH) $\lambda_{\max }$ 245 nm; IR (KBr film) v 2930, 2854, 2772, 1771, 1670, 1448, 1383, 1323, 1269, 1239, 1183, 1142, 1092, 1065, 1031, 956, $734 \mathrm{~cm}^{-1} ;{ }^{1} \mathrm{H}$ NMR/COSY $\left(500 \mathrm{MHz}, \mathrm{C}_{6} \mathrm{D}_{6}\right) \delta 6.27(1 \mathrm{H}, \mathrm{d}, J=$ $16.1 \mathrm{~Hz}), 5.40(1 \mathrm{H}, \mathrm{dd} ; J=8.2,16.1 \mathrm{~Hz}), 4.13(1 \mathrm{H}, \mathrm{dq}, J=6.3,6.3 \mathrm{~Hz}), 2.81(1 \mathrm{H}, \mathrm{br} \mathrm{d}, J=14.0$ $\mathrm{Hz}), 2.42(2 \mathrm{H}, \mathrm{m}), 2.26(1 \mathrm{H}, \mathrm{m}), 2.19(3 \mathrm{H}, \mathrm{s}), 1.86(1 \mathrm{H}, \mathrm{m}), 1.70-1.00(16 \mathrm{H}, \mathrm{m}), 1.19(3 \mathrm{H}, \mathrm{d}, J=$ $6.3 \mathrm{~Hz}), 1.07(3 \mathrm{H}, \mathrm{d}, J=6.1 \mathrm{~Hz}) ;{ }^{13} \mathrm{C}$ NMR/DEPT (50 MHz, $\left.\mathrm{C}_{6} \mathrm{D}_{6}\right) \delta 177.7(\mathrm{C}), 140.8(\mathrm{C}), 135.8$ $(\mathrm{CH}), 127.8(\mathrm{CH}), 123.7(\mathrm{C}), 80.8(\mathrm{CH}), 69.2(\mathrm{CH}), 59.7(\mathrm{CH}), 43.7(\mathrm{CH}), 41.0\left(\mathrm{CH}_{3}\right), 38.6$ $(\mathrm{CH}), 38.1(\mathrm{CH}), 36.2\left(\mathrm{CH}_{2}\right), 35.3\left(\mathrm{CH}_{2}\right), 35.0\left(\mathrm{CH}_{2}\right), 30.5\left(\mathrm{CH}_{2}\right), 28.0\left(\mathrm{CH}_{2}\right), 27.9\left(\mathrm{CH}_{2}\right), 26.7$ $\left(\mathrm{CH}_{2}\right), 24.7\left(\mathrm{CH}_{2}\right), 21.9\left(\mathrm{CH}_{3}\right), 21.1\left(\mathrm{CH}_{3}\right) ; \mathrm{MS} \mathrm{m} / \mathrm{z} 343$ (22) $\left[\mathrm{M}^{+}\right], 328$ (20), 314 (5), 300 (12), 270 (6), 230 (10), 199 (10), 171 (8), 149 (32), 125 (48), 112 (100), 91 (55), 58 (90).

(3S,3aR,8aR,9aR)-4-[(E)-2-((2S,6R)-1,2-Dimethylpiperidin-6-yl)ethenyl]-3-methyl-3a,5,6,7, 8,8a,9,9a-octahydro-3H-naphtho[2,3-c]furan-1-one (14b). Removal of the $N$-Boc protecting group of 28b was carried out as described above for $28 \mathbf{a}$ to give $\mathbf{1 4 b}(80 \%)$ as a solid: $\mathrm{R}_{\mathrm{f}}$ (isooctane/acetone 2:3) 0.20; UV (MeOH) $\lambda_{\max } 247 \mathrm{~nm}$; $[\alpha]^{20}{ }_{\mathrm{D}}-52.2\left(c 1.425, \mathrm{CHCl}_{3}\right)$; IR $(\mathrm{KBr}$ film) $\vee 2926,2843,2773,1784,1445,1384,1278,1179,1139,1088,1068,1032,998,958,908$, $873,762 \mathrm{~cm}^{-1}$; ${ }^{1} \mathrm{H}$ NMR/COSY $\left(500 \mathrm{MHz}, \mathrm{C}_{6} \mathrm{D}_{6}\right) \delta 5.56(1 \mathrm{H}, \mathrm{d}, J=16.0 \mathrm{~Hz}), 5.37(1 \mathrm{H}, \mathrm{dd} ; J=$ 8.4, 16.0 Hz), $3.88(1 \mathrm{H}, \mathrm{dq}, J=10.0,6.0 \mathrm{~Hz}), 2.86(1 \mathrm{H}, \mathrm{d}, J=13.0 \mathrm{~Hz}), 2.37(1 \mathrm{H}, \mathrm{dd}, J=8.1$, $14.0 \mathrm{~Hz}), 2.25(3 \mathrm{H}, \mathrm{s}), 2.15(1 \mathrm{H}, \mathrm{dt}, J=2.9,13.0 \mathrm{~Hz}), 1.98(1 \mathrm{H}, \mathrm{t}, J=12.8 \mathrm{~Hz}), 1.89(2 \mathrm{H}, \mathrm{m})$, $1.76(1 \mathrm{H}, \mathrm{dd}, J=1.8,13.0 \mathrm{~Hz}), 1.70-0.90(14 \mathrm{H}, \mathrm{m}), 1.29(3 \mathrm{H}, \mathrm{d}, J=6.0 \mathrm{~Hz}), 1.12(3 \mathrm{H}, \mathrm{d}, \mathrm{J}=$ 6.1Hz); ${ }^{13} \mathrm{C}$ NMR/DEPT (50 MHz, $\left.\mathrm{C}_{6} \mathrm{D}_{6}\right) \delta 175.2(\mathrm{C}), 139.5(\mathrm{C}), 139.4(\mathrm{CH}), 126.7(\mathrm{C}), 126.4$ $(\mathrm{CH}), 78.8(\mathrm{CH}), 68.7(\mathrm{CH}), 59.4(\mathrm{CH}), 51.6(\mathrm{CH}), 42.4(\mathrm{CH}), 40.8\left(\mathrm{CH}_{3}\right), 39.9(\mathrm{CH}), 36.2$ $\left(\mathrm{CH}_{2}\right), 35.2\left(\mathrm{CH}_{2}\right), 34.5\left(\mathrm{CH}_{2}\right), 31.4\left(\mathrm{CH}_{2}\right), 29.4\left(\mathrm{CH}_{2}\right), 28.6\left(\mathrm{CH}_{2}\right), 27.2\left(\mathrm{CH}_{2}\right), 24.6\left(\mathrm{CH}_{2}\right), 21.8$ $\left(\mathrm{CH}_{3}\right), 20.5\left(\mathrm{CH}_{3}\right)$; MS m/z $343(8)\left[\mathrm{M}^{+}\right], 328$ (7), 300 (5), 272 (3), 255 (2), 232 (4), 199 (2), 163 (4), 149 (25), 125 (18), $112(30), 84$ (70), 49 (100).

(3S,3aR,8aR,9aS)-4-((2S,6R)-1-tert-Butyloxycarbonyl-2-methylpiperidin-6-yl)ethynyl-3methyl-3a,5,6,7,8,8a,9,9a-octahydro-3H-naphtho[2,3-c]furan-1-one (29a). To a mixture of bis(triphenylphosphine)palladium(II) acetate $\left(\mathrm{Pd}\left(\mathrm{PPh}_{3}\right)_{2}(\mathrm{OAc})_{2}, 8.5 \mathrm{mg}, 0.001 \mathrm{mmol}\right)$, bromide 25a (15 mg, $0.05 \mathrm{mmol})$ and $\mathrm{Et}_{3} \mathrm{~N}(0.5 \mathrm{~mL})$ in $\mathrm{CH}_{3} \mathrm{CN}(2 \mathrm{~mL})$ was added a solution of alkyne 27 (23.5 mg, $0.1 \mathrm{mmol})$ in $\mathrm{CH}_{3} \mathrm{CN}(0.5 \mathrm{~mL})$ over a period of $30 \mathrm{~min}$. The reaction mixture was refluxed under Ar for $1 \mathrm{~h}$ (color change to brown), then cooled to $\mathrm{rt}$ and the volatiles were removed under reduced pressure. The residue was dissolved in isooctane/EtOAc 3:1 (5 mL) and passed through a pad of silica gel, which was rinsed with isooctane/EtOAc 3:1 (20 mL). After concentration, the residue was purified by HPLC on silica gel (isooctane/EtOAc 5:1) to yield 29a (17 mg, 76\%) as a colorless oil: $\mathrm{R}_{\mathrm{f}}$ (isooctane/EtOAc 4:1) 0.22; $[\alpha]^{20}{ }_{\mathrm{D}}+77.1$ (c $0.854, \mathrm{CHCl}_{3}$ ); 
IR $(\mathrm{KBr}$ film) v 2933, 2859, 1778, 1694, 1454, 1387, 1361, 1306, 1273, 1250, 1176, 1111, 1065 , $1028,954,862,773,732,641 \mathrm{~cm}^{-1} ;{ }^{1} \mathrm{H} \mathrm{NMR} / \mathrm{COSY}\left(500 \mathrm{MHz}, \mathrm{CDCl}_{3}\right) \delta 4.96(1 \mathrm{H}, \mathrm{t}, J=3.4$ $\mathrm{Hz}), 4.45(1 \mathrm{H}, \mathrm{dq}, J=8.0,6.1 \mathrm{~Hz}), 3.93(1 \mathrm{H}, \mathrm{m}), 3.10(1 \mathrm{H}, \mathrm{m}), 2.64(2 \mathrm{H}, \mathrm{m}), 2.20-1.70(12 \mathrm{H}$, $\mathrm{m}), 1.61(3 \mathrm{H}, \mathrm{d}, J=6.1 \mathrm{~Hz}), 1.47(9 \mathrm{H}, \mathrm{s}), 1.55-1.20(3 \mathrm{H}, \mathrm{m}), 1.27(3 \mathrm{H}, \mathrm{d}, J=6.7 \mathrm{~Hz}), 1.01(1 \mathrm{H}$, $\mathrm{ddd}, J=3.5,12.5,25.0 \mathrm{~Hz}$ ); ${ }^{13} \mathrm{C} \mathrm{NMR/DEPT}\left(50 \mathrm{MHz}, \mathrm{CDCl}_{3}\right) \delta 178.1(\mathrm{C}), 154.9(\mathrm{C}), 149.9$ (C), $109.4(\mathrm{C}), 94.7(\mathrm{C}), 81.4(\mathrm{CH}), 80.8(\mathrm{C}), 79.7(\mathrm{C}), 47.9(\mathrm{CH}), 46.7(\mathrm{CH}), 43.9(\mathrm{CH}), 39.0$ $(\mathrm{CH}), 36.8(\mathrm{CH}), 34.7\left(\mathrm{CH}_{2}\right), 31.9\left(\mathrm{CH}_{2}\right), 28.8\left(\mathrm{CH}_{2}\right), 28.5\left(\mathrm{CH}_{3}\right), 27.4\left(\mathrm{CH}_{2}\right), 27.1\left(\mathrm{CH}_{2}\right), 26.5$ $\left(\mathrm{CH}_{2}\right), 25.7\left(\mathrm{CH}_{2}\right), 21.1\left(\mathrm{CH}_{3}\right), 20.7\left(\mathrm{CH}_{3}\right), 15.0\left(\mathrm{CH}_{2}\right) ; \mathrm{MS}$ m/z 371 (24), 326 (8), 299 (10), 271 (14), 240 (8), 213 (10), 149 (10), 142 (30), 98 (35), 57 (100).

(3S,3aR,8aR,9aR)-4-((2S,6R)-1-tert-Butyloxycarbonyl-2-methylpiperidin-6-yl)ethynyl-3methyl-3a,5,6,7,8,8a,9,9a-octahydro-3H-naphtho[2,3-c]furan-1-one (29b). Bromide 25b was reacted with alkyne 27 as described above for bromide 25a to give 29b (73\%) as a solid: $\mathrm{R}_{\mathrm{f}}$ (isooctane/EtOAc 4:1) 0.32; mp $129{ }^{\circ} \mathrm{C} ;[\alpha]^{20}{ }_{\mathrm{D}}+57.2\left(\right.$ c $\left.0.552, \mathrm{CHCl}_{3}\right)$; IR $(\mathrm{KBr}) \vee 2938$, 2852, 1771, 1687, 1478, 1450, 1397, 1363, 1326, 1307, 1285, 1264, 1236, 1180, 1150, 1113, 1081, 1040, 1002, 962, 909, 882, 864, 847, 770, 701, $608 \mathrm{~cm}^{-1} ;{ }^{1} \mathrm{H}$ NMR/COSY (500 MHz, $\left.\mathrm{CDCl}_{3}\right) \delta 4.97(1 \mathrm{H}, \mathrm{t}, J=3.0 \mathrm{~Hz}), 4.36(1 \mathrm{H}, \mathrm{dq}, J=10.2,6.1 \mathrm{~Hz}), 3.93(1 \mathrm{H}, \mathrm{m}), 3.00(1 \mathrm{H}, \mathrm{m})$, $2.37(2 \mathrm{H}, \mathrm{m}), 2.13(1 \mathrm{H}, \mathrm{m}), 1.61(3 \mathrm{H}, \mathrm{d}, J=6.1 \mathrm{~Hz}), 1.46(9 \mathrm{H}, \mathrm{s}), 2.00-1.20(15 \mathrm{H}, \mathrm{m}), 1.26(3 \mathrm{H}$, $\mathrm{d}, J=6.7 \mathrm{~Hz}) ;{ }^{13} \mathrm{C} \mathrm{NMR/DEPT}\left(50 \mathrm{MHz}, \mathrm{CDCl}_{3}\right) \delta 176.0(\mathrm{C}), 154.9(\mathrm{C}), 151.7$ (C), $110.3(\mathrm{C})$, $95.8(\mathrm{C}), 80.1(\mathrm{CH}), 79.7(\mathrm{C}), 78.3(\mathrm{C}), 49.9(\mathrm{CH}), 47.9(\mathrm{CH}), 43.8(\mathrm{CH}), 42.2(\mathrm{CH}), 39.6(\mathrm{CH})$, $36.0\left(\mathrm{CH}_{2}\right), 33.0\left(\mathrm{CH}_{2}\right), 28.5\left(\mathrm{CH}_{2}\right), 28.4\left(\mathrm{CH}_{3}\right), 27.6\left(\mathrm{CH}_{2}\right), 27.3\left(\mathrm{CH}_{2}\right), 27.1\left(\mathrm{CH}_{2}\right), 26.6\left(\mathrm{CH}_{2}\right)$, $21.1\left(\mathrm{CH}_{3}\right), 19.6\left(\mathrm{CH}_{3}\right), 14.8\left(\mathrm{CH}_{2}\right) ; \mathrm{MS} \mathrm{m} / \mathrm{z} 427\left[\mathrm{M}^{+}\right], 371$ (22), 354 (2), 326 (12), 284 (16), 256 (5), 230 (5), 185 (8), 142 (50), 115 (20), 98 (62), 57 (100).

(3S,3aR,8aR,9aS)-4-((2S,6R)-1,2-Dimethylpiperidin-6-yl)ethynyl-3-methyl-3a,5,6,7,8,8a,9,

9a-octahydro-3H-naphtho[2,3-c]furan-1-one (15a). Removal of the $N$-Boc protecting group of 29a was carried out as described above for 28a to give 15a (75\%) as a colorless oil: $R_{f}$ (isooctane/acetone 2:3) 0.38; $[\alpha]^{20}{ }_{\mathrm{D}}+10.1$ (c 0.976, $\left.\mathrm{CHCl}_{3}\right)$; IR $(\mathrm{KBr}$ film) v 2932, 2858, 2787 , 1778, 1453, 1382, 1333, 1287, 1252, 1194, 1129, 1065, 1032, 954, 834, 800, 728, 662, $598 \mathrm{~cm}^{-1}$; ${ }^{1} \mathrm{H}$ NMR/COSY $\left(500 \mathrm{MHz}, \mathrm{C}_{6} \mathrm{D}_{6}\right) \delta 4.21(1 \mathrm{H}, \mathrm{dq}, J=7.8,6.1 \mathrm{~Hz}), 3.70(1 \mathrm{H}, \mathrm{br} \mathrm{s}), 3.24(1 \mathrm{H}$, br $\mathrm{d}, J=14.1 \mathrm{~Hz}), 2.50(1 \mathrm{H}, \mathrm{dtd}, J=2.5,6.3,17.0 \mathrm{~Hz}), 2.28(3 \mathrm{H}, \mathrm{s}), 2.24(2 \mathrm{H}, \mathrm{m}), 1.80-1.00(15 \mathrm{H}$, m), $1.43(3 \mathrm{H}, \mathrm{d}, J=6.1 \mathrm{~Hz}), 0.99(3 \mathrm{H}, \mathrm{d}, J=6.2 \mathrm{~Hz}), 0.75(1 \mathrm{H}, \mathrm{ddd}, \mathrm{J}=3.6,12.8,25.3 \mathrm{~Hz}, 1 \mathrm{H})$; ${ }^{13} \mathrm{C} \mathrm{NMR/DEPT}\left(50 \mathrm{MHz}, \mathrm{C}_{6} \mathrm{D}_{6}\right) \delta 176.8(\mathrm{C}), 148.8(\mathrm{C}), 110.5(\mathrm{C}), 92.1(\mathrm{C}), 85.9(\mathrm{C}), 80.5$ $(\mathrm{CH}), 55.6(\mathrm{CH}), 53.2(\mathrm{CH}), 47.2(\mathrm{CH}), 41.3\left(\mathrm{CH}_{3}\right), 39.1(\mathrm{CH}), 36.9(\mathrm{CH}), 35.2\left(\mathrm{CH}_{2}\right), 35.0$ $\left(\mathrm{CH}_{2}\right), 32.6\left(\mathrm{CH}_{2}\right), 31.8\left(\mathrm{CH}_{2}\right), 28.8\left(\mathrm{CH}_{2}\right), 27.0\left(\mathrm{CH}_{2}\right), 26.0\left(\mathrm{CH}_{2}\right), 21.3\left(\mathrm{CH}_{2}\right), 21.1\left(\mathrm{CH}_{3}\right), 21.0$ $\left(\mathrm{CH}_{3}\right) ; \mathrm{MS} \mathrm{m} / \mathrm{z}$ 341(29) [M $\left.\mathrm{M}^{+}\right], 326$ (100), 312 (15), 298 (20), 270 (25), 242 (12), 197 (10), 155 (15), 149 (35), 115 (48), 96 (70), 64 (40), 42 (90).

(3S,3aR,8aR,9aR)-4-((2S,6R)-1,2-Dimethylpiperidin-6-yl)ethynyl-3-methyl-3a,5,6,7,8,8a,9, 9a-octahydro-3H-naphtho[2,3-c]furan-1-one (15b). Removal of the $N$-Boc protecting group of 29b was carried out as described above for $28 a$ to give $15 b(78 \%)$ as a colorless oil: $R_{f}$ (isooctane/acetone 2:3) 0.40; $[\alpha]^{20}{ }_{\mathrm{D}}-2.0\left(\right.$ ( $\left.0.589, \mathrm{CHCl}_{3}\right)$; IR $(\mathrm{KBr}$ film) $\vee 2932,2854,2782$, $1787,1446,1388,1333,1286,1171,1142,1093,1050,1031,1003,962,912,888,691,595$ 
$\mathrm{cm}^{-1} ;{ }^{1} \mathrm{H}$ NMR/COSY (500 MHz, $\left.\mathrm{C}_{6} \mathrm{D}_{6}\right) \delta 4.08(1 \mathrm{H}, \mathrm{dq}, J=9.8,6.0 \mathrm{~Hz}), 3.69(1 \mathrm{H}, \mathrm{br} \mathrm{s}), 3.17$ $(1 \mathrm{H}, \mathrm{dd}, J=2.3,13.5 \mathrm{~Hz}), 2.48(1 \mathrm{H}, \mathrm{dtd}, J=2.4,6.3,17.2 \mathrm{~Hz}), 2.27(3 \mathrm{H}, \mathrm{s}), 2.05(1 \mathrm{H}, \mathrm{dt}, J=$ 2.9, $12.9 \mathrm{~Hz}), 1.98(1 \mathrm{H}, \mathrm{m}), 1.80-0.80(16 \mathrm{H}, \mathrm{m}), 1.52(3 \mathrm{H}, \mathrm{d}, J=6.0 \mathrm{~Hz}), 0.98(3 \mathrm{H}, \mathrm{d}, J=6.2$ $\mathrm{Hz}) ;{ }^{13} \mathrm{C}$ NMR/DEPT (50 MHz, $\left.\mathrm{C}_{6} \mathrm{D}_{6}\right) \delta 174.6(\mathrm{C}), 150.7(\mathrm{C}), 111.5(\mathrm{C}), 93.5(\mathrm{C}), 83.3(\mathrm{C}), 79.2$ $(\mathrm{CH}), 55.7(\mathrm{CH}), 53.2(\mathrm{CH}), 50.2(\mathrm{CH}), 42.3\left(\mathrm{CH}_{3}\right), 41.3(\mathrm{CH}), 39.7(\mathrm{CH}), 36.0\left(\mathrm{CH}_{2}\right), 35.2$ $\left(\mathrm{CH}_{2}\right), 33.6\left(\mathrm{CH}_{2}\right), 31.8\left(\mathrm{CH}_{2}\right), 29.1\left(\mathrm{CH}_{2}\right), 27.9\left(\mathrm{CH}_{2}\right), 26.9\left(\mathrm{CH}_{2}\right), 21.3\left(\mathrm{CH}_{2}\right), 21.0\left(\mathrm{CH}_{3}\right), 20.0$ $\left(\mathrm{CH}_{3}\right) ; \mathrm{MS} \mathrm{m} / \mathrm{z} 341$ (29) $\left[\mathrm{M}^{+}\right], 326$ (100), 312 (14), 298 (15), 270 (18), 254 (10), 226 (10), 197 (15), 155 (12), 141 (20), 115 (30), 96 (60), 42 (75).

Binding affinity studies. Materials. $\left[{ }^{3} \mathrm{H}\right]-\mathrm{NMS}$ (about $80 \mathrm{Ci} / \mathrm{mmol}$ ) was obtained from Du Pont-New England Nuclear. Atropine sulfate was obtained from Sigma (St. Louis, FL). The cell culture medium, flasks and foetal calf serum were obtained from GIBCO Life Technologies (Gent, Belgium). All other chemicals were of the highest grade available. The drug stock solutions were prepared in $50 \%$ ethanol water at a $10 \mathrm{mM}$ concentration. All subsequent dilutions were performed in water, in order to keep the ethanol concentration in the assays below $1 \%$; at these concentrations ethanol does not interfere with muscarinic binding. Addition of an approximately equimolar $\mathrm{HCl}$ concentration was necessary to maintain the drugs in solution in water.

Cell culture. $\mathrm{CHO}$ cell lines, transfected respectively with plasmids encoding each of the four muscarinic receptor subtypes $\left(\mathrm{hM}_{1}, \mathrm{hM}_{2}, \mathrm{hM}_{3}\right.$, and $\left.\mathrm{hM}_{4}\right)$, were obtained from Dr. N. Buckley (London, UK). They were maintained in Dulbecco's MEM enriched with 10\% Foetal calf serum, 200 I.U./mL penicillin and $100 \mu \mathrm{g} / \mathrm{mL}$ streptomycin. The stock culture medium contained 0.5 $\mu \mathrm{g} / \mathrm{mL}$ geneticin to maintain selective pressure; the subcultures prepared for binding studies were maintained in a medium without geneticin. Confluent cells were harvested by scraping with a rubber policeman and centrifuged. The pellet was homogenized in a $1 \mathrm{mM}$ sodium bicarbonate solution, and stored in liquid nitrogen until use.

$\left[{ }^{3} \mathbf{H}\right]$-NMS binding. $\mathrm{CHO}$ cell homogenates (at a concentration equivalent to about 0.05 to 0.1 $\mathrm{nM}$ muscarinic receptors in the binding assays) were incubated at $25{ }^{\circ} \mathrm{C}$, in the presence of $\left[{ }^{3} \mathrm{H}\right]-$ NMS and of the indicated concentrations of the unlabelled drugs, in $1.0 \mathrm{~mL}$ of a $50 \mathrm{mM}$ sodium phosphate buffer ( $\mathrm{pH}$ 7.4) enriched with $2 \mathrm{mM} \mathrm{MgCl}_{2}$. Non-specific binding was defined as binding in the presence of $10 \mu \mathrm{M}$ atropine. The tracer concentrations used were $0.25 \mathrm{nM}$ for competition curves with $\mathrm{hM}_{1}, \mathrm{hM}_{3}$ or $\mathrm{hM}_{4}$ receptors, or $0.8 \mathrm{nM}$ for competition curves with $\mathrm{hM}_{2}$ receptors. To verify the tracer affinities at these receptors, saturation curves were obtained by varying the $\left[{ }^{3} \mathrm{H}\right]-\mathrm{NMS}$ concentration between 0.05 and $3.0 \mathrm{nM}$. At $25^{\circ} \mathrm{C}$, an incubation period of $2 \mathrm{~h}$ for incubations with $\mathrm{hM}_{1}, \mathrm{hM}_{2}$ or $\mathrm{hM}_{4}$ receptors, $4 \mathrm{~h}$ for incubations with $\mathrm{hM}_{3}$ receptors was sufficient to achieve equilibrium tracer binding. The incubations were terminated by filtration over glass microfiber filters $\mathrm{C}(\mathrm{K}-\mathrm{LAB})$, pre-soaked in $0.01 \%$ polyethyleneimine (Sigma, St Louis, FL) to reduce non-specific binding. The filters were rinsed 3 times with $2 \mathrm{~mL}$ of ice-cold $50 \mathrm{mM}$ sodium phosphate buffer (pH 7.4) then soaked at least $4 \mathrm{~h}$ in "Lumagel Plus" (Lumac Lsc.) and the radioactivity counted in a Packard 1500 Tricarb liquid scintillation analyser. The total tracer binding (in the absence of competitor) was kept below 20\% (typically between 10 
and $15 \%$ ) of the radioactivity offered, to avoid alterations of the free tracer concentration with increasing competitor concentrations. Non-specific binding was always below $1 \%$ of the radioactivity offered (that is, below $10 \%$ of the bound radioactivity). Duplicate determinations were always within 5\% (typically $3 \%$ ) of each other.

Data Analysis. All competition curves were performed in duplicate, and repeated twice. The experimental data were analyzed by non-linear curve fitting, using the Graph Pad program. The tracer affinity was determined in the same experiment by saturation curve analysis. The unlabeled drugs $\mathrm{K}_{\mathrm{i}}$ values were calculated assuming that they inhibited competitively [ $\mathrm{H}$ ]-NMS binding, using the Cheng and Prusoff equation.

\section{Acknowledgments}

The authors thank the FWO (Fonds voor Wetenschappelijk Onderzoek-Vlaanderen; G003600) and the "Fonds de la Recherche Scientifique Médicale" (3.4504.99) for financial assistance. M. W. thanks Dr. N. J. Buckley (University of Leeds, UK) for the generous gift of the stably transferred CHO cell lines. G.V.C. thanks the IWT (Instituut voor Wetenschappelijk en Technologisch Onderzoek) for a scholarship.

\section{References}

* To whom correspondence should be addressed; Tel. +32 926444 63; Fax +32 92644998.

1. Ritchie, E.; Taylor, W. C. The Galbulimima alkaloids, in The Alkaloids, Vol. 9; Manske, R. H. F., Ed.; Academic Press, New York, 1967; p. 529-543.

2. Pinkey, J. T.; Ritchie, E.; Taylor, W. C. Austr. J. Chem. 1961, 14, 106.

3. Fridrichsons, J.; Mathieson, A. McL. Acta Crystallogr. 1962, 15, 119.

4. For some early reports, see: (a) Gilani, S. A. H.; Cobbin, L. B. Naunyn-Schmiedeberg's Arch. Pharmacol. 1986, 332, 16. (b) Choo, L. K.; Mitchelson, F. J. Pharm. Pharmacol. 1988, 40, 288. (c) Wang, J.-X.; Roeske, W. R.; Wang, W.; Yamamura, H. Y. Brain Res. 1988, 446, 155. (d) Eglen, R. M.; Montgomery, W. W.; Dainty, I. A.; Dubuque, L. K.; Whiting, R. L. Br. J. Pharmacol. 1988, 95, 1031. (e) Lazareno, S.; Roberts, F. F. Br. J. Pharmacol. 1989, 98, 309.

5. Dale, H. H. J. Pharmacol. Exp. Ther. 1914, 6, 147.

6. Wess, J.; Buhl, T.; Lambrecht, G.; Mutschler, E. Cholinergic Receptors in Comprehensive Medicinal Chemistry, Vol. 3; Emmett, J. C., Ed.; Pergamon Press: Oxford, UK, 1990; p. 423.

7. (a) Peralta, E. G.; Ashkenazi, A.; Winslow, J. W.; Smith, D. H.; Ramachandran, J.; Capon, D. J. EMBO J. 1987, 6, 3923. (b) Bonner, T. I.; Buckley, N. J.; Young, A. C.; Brann, M. R. 
Science 1987, 237, 527. (c) Kubo, T.; Fukuda, K.; Mikami, A.; Maeda, A.; Takahashi, H.; Mishina, M.; Haga, T.; Haga, K.; Ichiyama, A.; Kangawa, K. Nature 1986, 323, 411. (d) Kubo, T.; Maeda, A.; Sugimoto, K.; Akiba, I.; Mikami, A.; Takahashi, H.; Haga, T.; Haga, K.; Ichiyama, A.; Kangawa, K. FEBS Lett. 1986, 209, 367. (e) Bonner, T. I.; Young, A. C.; Brann, M. R.; Buckley, N. J. Neuron 1988, 1, 403.

8. Dörje, F.; Wess, J.; Lambrecht, G.; Tacke, R.; Mutschler, E.; Brann, M. R. J. Pharmacol. Exp. Ther. 1991, 256, 727.

9. Buckley, N. J.; Bonner, T. I.; Brann, M. R. J. Neurosci. 1988, 8, 4646.

10. (a) Bartus, R. T.; Dean III, R. L.; Beer, B.; Lippa, A. S. Science, 1982, 217, 408. (b) Coyle, J. T.; Price, D. L.; DeLong, M. R. Science 1983, 219, 1184.

11. Summers, W. K.; Majovski, L. V.; Marsh, G. M.; Tachiki, K.; Kling, A. New Engl. J. Med. 1986, 315, 1241.

12. (a) Svensson, A.-L.; Alufuzoff, I.; Nordberg, A. Brain Research 1992, 596, 142. (b) Fisher, A. Jpn. J. Pharmacol. 2000, 84, 101

13. (a) Mash, D. C.; Flynn, D. D.; Potter, L. T. Science 1985, 228, 1115. (b) McKinney, M.; Coyle, J. T. Mayo Clin. Proc. 1991, 66, 1225. (c) Greenlee, W.; Clader, J.; Asberom, T.; McCombie, S.; Ford, J.; Guzik, H.; Kozlowski, J.; Li, S.; Liu, C.; Lowe, D.; Vice, S.; Zhao, H.; Zhou, G.; Billard, W.; Binch, H.; Crosby, R.; Duffy, R.; Lachowicz, J.; Coffin, V.; Watkins, R.; Ruperto, V.; Strader, C.; Taylor, L.; Cox, K. Farmaco 2001, 56, 247.

14. (a) Brumner, F. Br. J. Pharmacol. 1989, 97, 572. (b) Mitchelson, F. Pharmac. Ther. 1988, $37,357$.

15. Hammer, R.; Berrie, C. P.; Birdsall, N. J. M.; Burgen, A. S. V.; Hulme, E. C. Nature 1980, 283, 90.

16. For a review on the molecular biology, pharmacology, and brain distribution of subtypes of the muscarinic receptor, see: Caulfield, M. P.; Birdsall, N. J. Pharmacol. Rev. 1998, 50, 279.

17. (a) Lee, N. H.; El-Fakahany, E. E. Eur. J. Pharmacol. 1990, 179, 225. (b) Birdsall, N. J.; Lazareno, S.; Popham, A.; Saldanha, J. Life Sci. 2001, 68, 2517.

18. Miller, J. H.; Aagaard, P. J.; Gibson, V. A., McKinney, M. J. Pharmacol. Exp. Ther. 1992, $263,663$.

19. Waelbroeck, M.; Tastenoy, M.; Camus, J.; Christophe, J. Molecular Pharmacology 1990, 38, 267.

20. Darroch, S. A.; Taylor, W. C.; Choo, L. K.; Mitchelson, F. Eur. J. Pharmacol. 1990, 182, 131.

21. (a) Kozikowski, A. P.; Fauq, A. H.; Muller, J. H.; McKinney, M. Bioorg. Med. Chem. Lett. 1992, 2, 797. (b) Malaska, M. J.; Fauq, A. H.; Kozikowski, A. P.; Aagaard, P. J.; McKinney, M. Bioorg. Med. Chem. Lett. 1993, 3, 1247. (c) Malaska, M. J.; Fauq, A. H.; Kozikowski, A. P.; Aagaard, P. J.; McKinney, M. Bioorg. Med. Chem. Lett. 1995, 5, 61.

22. Doller, D.; Chackalamannil, S.; Czarniecki, M.; McQuade, R.; Ruperto, V. Bioorg. Med. Chem. Lett. 1999, 9, 901. 
23. Wang, J.; Chackalamannil, L. S.; Chang, W.; Greenlee, W.; Ruperto, V.; Duffy, R. A.; McQuade, R.; Lachowicz, J. E. Bioorg. Med. Chem. Lett. 2001, 11, 891.

24. Gao, L.-J.; Waelbroeck, M.; Hofman, S.; Van Haver, D.; Milanesio, M.; Viterbo, D.; De Clercq, P. J. Bioorg. Med. Chem. Lett. 2002, 12, 000.

25. (a) Hart, D. J.; Wu, W.-L.; Kozikowski, A. P. J. Am. Chem. Soc. 1995, 117, 9369. (b) Hart, D. J.; Li, J.; Wu, W. L. Kozikowski, A. P. J. Org. Chem. 1997, 62, 5023.

26. (a) Chackalamannil, S.; Davies, R. J.; Asberom, T.; Doller, D.; Leone, D. J. Am. Chem. Soc. 1996, 118, 9812. (b) Chackalamannil, S.; Davies, R. J.; Wang, Y.; Asberom, T.; Doller, D.; Wong, J.; Leone, D.; McPhail, A. T. J. Org. Chem. 1999, 64, 1932.

27. Takadoi, M.; Katoh, T.; Ishiwata, A. Terashima, S. Tetrahedron Lett. 1999, 40, 3399.

28. Hofman, S.; Gao, L.-J.; Van Dingenen, H.; Hosten, N. G. C.; Van Haver, D.; De Clercq, P. J.; Milanesio, M.; Viterbo, D. Eur. J. Org. Chem. 2001, 2851.

29. For reviews on the IMDA reaction, see: (a) Fallis, A. G. Can. J. Chem. 1984, 62, 183. (b) Ciganek, E. Org. React. 1984, 32, 1. (c) Craig, D. Chem. Soc. Rev. 1987, 187. (d) Roush, W. R. In Comprehensive Organic Synthesis, Vol. 5; Trost, B. M.; Fleming, I.; Paquette, L. A., Eds.; Pergamon: Oxford, 1991; p 513-550.

30. (a) De Baecke, G.; De Clercq, P. J. Tetrahedron Lett. 1995, 36, 7515. (b) Hofman, S.; De Baecke, G.; Kenda, B.; De Clercq, P. J. Synthesis 1998, 479.

31. Baldwin, J. E.; Chesworth, R.; Parker, J. S.; Russell, T. Tetrahedron Lett. 1995, 36, 9551.

32. Chackalamannil, S.; Davies, R.; McPhail, A. T. Org. Lett. 2001, 3, 1427.

33. (a) For a preliminary account, see: Van Cauwenberge, G.; Gao, L.-J.; Van Haver, D.; Milanesio, M.; Viterbo, D.; De Clercq, P. J. Org. Lett. 2002, 4, 1579. (b) For a recent and almost identical approach, see: Wong, L. S.-M.; Sharp, L. A.; Xavier, N. M. C.; Turner, P.; Sherburn, M. S. Org. Lett. 2002, 4, 1955.

34. (a) He, J.-F.; Wu, Y.-L. Tetrahedron 1988, 44, 1933. (b) See also: Roush, W. R. In Advances in Cycloaddition, Vol. 2; Curran, D. P., Ed.; Jai Press, Greenwich, CT, 1990; pp 91.

35. Cayzer, T. N.; Wong, L. S.-M.; Turner, P.; Paddon-Row, M. N.; Sherburn, M. S. Chem. Eur. J. 2002, 8, 739.

36. Massad, S. K.; Hawkins, S. D.; Baker, D. C. J. Org. Chem. 1983, 48, 5180.

37. Corey, E. J.; Fuchs, P. L. Tetrahedron Lett. 1972, 3769.

38. (a) Trost. B. M.; Mueller, T. J. J.; Martinez, J. J. Am. Chem. Soc. 1995, 117, 1888. (b) For the corresponding (R)-enantiomer, see: Marshall, J. A.; Xie, S. J. Org. Chem. 1995, 60, 7230 .

39. (a) Stille, J. K. Angew. Chem. Int. Ed. Engl. 1986, 25, 508. (b) Farina, V.; Krishnamurthy, V.; Scott, W. J. Org. React. 1997, 50, 1.

40. Wulff, W. D.; Peterson, G. A.; Bauta, W. E.; Chan, K.-S.; Faron, K. L.; Gilbertson, S. R.; Kaesler, R. W.; Yang, D. C.; Murray, C. K. J. Org. Chem. 1986, 51, 277.

41. (a) Shen, W.; Wang, L. J. Org. Chem. 1999, 64, 8873. (b) Uenishi, J.; Kawahama, R.; Yonemitsu, O.; Tsuji, J. J. Org. Chem. 1998, 63, 8965. 
42. Precursor $\mathbf{2 4}$ and the adducts $25 \mathbf{a}$ and $\mathbf{2 5 b}$ are sensitive to acid. In the absence of a trace of DIPEA, the yield varies due to partial decomposition of precursor and adducts at the high temperature.

43. The relative steric energies calculated for 25a, 25b, 25c, and 25d are 0.0, 9.9, 3.3, and 14.6 $\mathrm{kJ} \mathrm{mol}^{-1}$, respectively. Calculated by the MM2* force field implementation of MacroModel using the program's default parameters, see: MacroModel - An Integrated Software System for Modeling Organic and Bioorganic Molecules using Molecular Mechanics: Mohamadi, F.; Richards, N. G. J.; Guida, W. C.; Liskamp, R.; Lipton, M.; Caufield, C.; Chang, G.; Hendrickson, T.; Still, W. C. J. Comput. Chem. 1990, 11, 440.

44. (a) Capella, L.; Degl'Innocenti, A.; Mordini, A.; Reginato, G.; Ricci, A.; Seconi, G. Synthesis 1991, 1201. (b) Hutringer, M. H.; Singer, R. D.; Oehlschlager, A. C. J. Am. Chem. Soc. 1990, 112, 9397.

45. Sonogashira, K.; Tohda, Y.; Hagihara, N. Tetrahedron Lett. 1975, 4467.

46. Under the typical Sonogashira coupling reaction conditions, no formation of 29a and 29b was observed; either no reaction took place (in the presence of $\mathrm{CuI}$ ) or the homo coupling product of 27 was formed (in the absence of $\mathrm{CuI}$ ). The use of $\mathrm{CH}_{3} \mathrm{CN}$ as solvent is crucial. In other solvent systems such as $\mathrm{DMF}_{-} \mathrm{Et}_{2} \mathrm{NH}$, toluene- $\mathrm{Et}_{2} \mathrm{NH}$, piperidine, $\mathrm{Et}_{2} \mathrm{NH}$, and pyrrolidine no coupling reaction took place. In addition, 27 should be added slowly otherwise the yield is poor.

47. For an account in depth about the scope and limitations of the IMDA reaction of pentadienyl acrylates, see reference 35 and references cited therein.

48. Turner, C. I.; Williamson, R. M.; Paddon-Row, M. N.; Sherburn, M. S. J. Org. Chem. 2001, $66,3963$.

49. White, J. D.; Demnitz, F. W. J.; Oda, H.; Hassler, C.; Snyder, J. P. Org. Lett. 2000, 2, 3313.

50. Hoffmann, R. W. Chem. Rev. 1989, 89, 1841.

51. Waelbroeck, M.; Lazareno, S.; Pfaff, O.; Friebe, T.; Tastenoy, M.; Mutschlee, E.; Lambrecht, G. Br. J. Pharmacol. 1996, 119, 1319. 